\title{
PROCEDURES FOR ASSESSMENT OF CUMULATIVE IMPACTS OF SURFACE MINING ON THE HYDROLOGIC BALANCE
}

By Alan M. Lumb

Prepared in cooperation with the

Office of Surface Mining Reclamation and Enforcement

U.S. Geological Survey

Open-File Report $82-334$

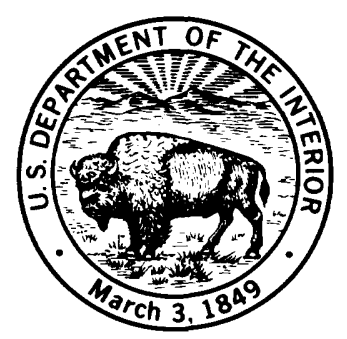


UNITED STATES DEPARTMENT OF THE INTERIOR

JAMES G. WATT, Secretary

GEOLOGICAL SURVEY

Dallas L. Peck, Director

For further information write to:

Chief Hydrologist

U.S. Geological Survey

415 National Center

Reston, Virginia 22092 
Conversion Table.................. . . . v v

Abstract .......................... . . . . 1

Introduction ......................... 1

Purpose and scope ...................... 1

Legislative requirements . . . . . . . . . . . . 2

Defiñitions ........................ . . . . . 3

Hydrologic balance ..................... . . . 5

Material damage ..................... . . . . 7

Cumulative impact techniques . . . . . . . . . . . . . 9

Guidelines and matrix . . . . . . . . . . . . . . . . . 10

General approach .................... . . . 10

Water-quality standards and criteria . . . . . . . . . 10

Hydrologic activity profile . . . . . . . . . . . . 10

Impact matrix . . . . . . . . . . . . . . . . . 12

Ouantifying impacts . . . . . . . . . . . . . . . . 12

No impact ......................... 12

Minor impact ..................... 15

Low flow ...................... 15

Flood frequency ..................... 16

Stage/surface area/velocity............... 17

Salts and heavy metals ................ 17

Suspended sediment ................... 17

Summary . . . . . . . . . . . . . . . . 19

Major impact ...................... 20

Models .................... . . 20

Input .......................... 22

Output . . . . . . . . . . . . . . . . . 22

Implementation ..................... 22

Computer requirements . . . . . . . . . . . . 23

Calibration/verification .............. 23

Data base and users manual ............. . . 24

Staff and training ................. 24

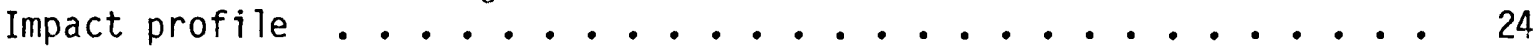

Adequacy of hydrologic evaluations for cumulative

impact assessment . . . . . . . . . . . . . 26

Case study . . . . . . . . . . . . . . . . . . . 26

Hydrologic activity profile . . . . . . . . . . . . 26

Impact matrix . . . . . . . . . . . . . . . . . 28

Minor impact . . . . . . . . . . . . . . . . 28

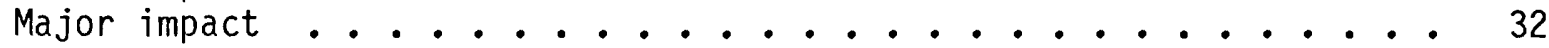

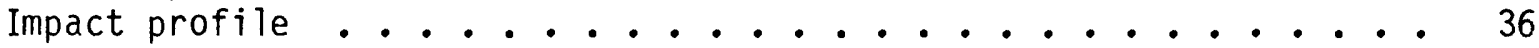

Comparison of major and minor impact analysis... . . . . . 36

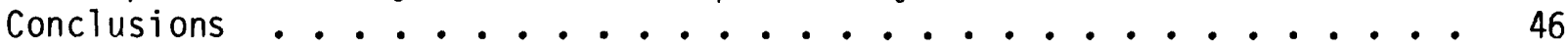

Future work . . . . . . . . . . . . . . . . . . . 46

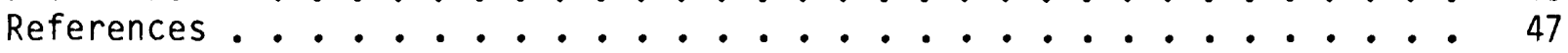




\section{TABLES}

Page

Table 1.--Distribution of annual rainfall . . . . . . . . 5 2.-- Impact matrix ................. 14

3.--Impact matrix--Tug Fork, W. Va. . . . . . . . . 29

4.--Flow characteristics for the permit area ....... 30

5.--Results of minor impact analysis .......... 31

6.--Statistics--simulated flow (1954-1978), mean

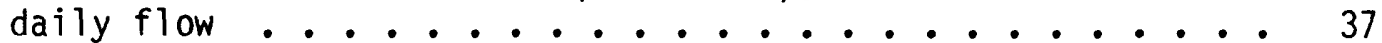

7.--Statistics--simulated flow (1954-1978), minimum

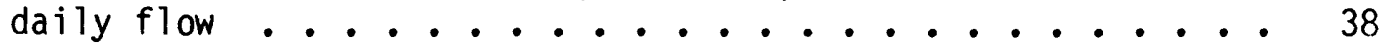

8.--Statistics--simulated flow (1954-1978), maximum daily flow . . . . . . . . . . . . . . 39

9.--Statistics--simulated flow (1954-1978), mean of the annual maximum daily flow . . . . . . . . . 40

10.--Comparison of minor and major impact analysis techniques .................... 41 
Figure 1.--Typical distribution of annual rainfall . . . . . . 6 2.--Steps for a cumulative impact assessment . . . . . . 11 3.--Hydrologic activity profile, Tug Fork, W. Va. . . . . 13 4.--Impact profile example . . . . . . . . . . 25 5.--Location of the Tug Fork basin........ 27 6.--Daily hydrographs, Tug Fork at Kermit, W. Va., 1956 . . . 33 7.--Mean monthly flow, Tug Fork at Kermit, W. Va., 1980 . . . 34 8.--Annual flows, Tug Fork at Kermit, W. Va. . . . . . . 35 9.--Flow duration, simulated flow, Jacob Fork, winter period ................. . . 42

10.--Flow duration, simulated flow, Jacob Fork, summer period .................... 43

11.--Impact profile, minimum daily flow, summer period . . . 44 12.-- Impact profile, maximum daily flow, summer period . . . 45 
METRIC (SI) CONVERSION FACTORS

\begin{tabular}{lcl}
\hline Multiply & By & To obtain metric units \\
\hline inch (in) & 25.4 & millimeter $(\mathrm{mm})$ \\
foot $(\mathrm{ft})$ & 0.3048 & meter $(\mathrm{m})$ \\
foot per second $(\mathrm{ft} / \mathrm{s})$ & $0.3048^{i}$ & meter per second $(\mathrm{m} / \mathrm{s})$ \\
acre & 0.4047 & $\begin{array}{l}\text { hectare } \\
\text { square meter }\left(\mathrm{m}^{2}\right)\end{array}$ \\
square mile $\left(\mathrm{mi}^{2}\right)$ & 4047. & square kilometer $\left(\mathrm{km}^{2}\right)$ \\
cubic foot per second $\left(\mathrm{ft}^{3} / \mathrm{s}\right)$ & 28.32 & $\begin{array}{l}\text { liters per second }(\mathrm{L} / \mathrm{s}) \\
\text { cubic meters per second }\left(\mathrm{m}^{3} / \mathrm{s}\right)\end{array}$
\end{tabular}


PROCEDURES FOR ASSESSMENT OF CUMULATIVE IMPACTS

OF SURFACE MINING ON THE HYDROLOGIC BALANCE

By Alan M. Lumb

\begin{abstract}
The Surface Mining Control and Reclamation Act of 1977 requires the designated regulatory authority of each State to assess the probable cumulative impacts of all anticipated mining upon the hydrology of the area. The Act also states that quantity and quality of water is to be considered as well as seasonal variations in flow.

Techniques were developed to assess the probable cumulative impacts including concepts of a hydrologic activity profile, an impact matrix, and an impact profile. An activity profile of cumulative drainage area versus river miles downstream from the surface-mining site is constructed that shows major water uses, flood-prone areas, and stream classifications. From the summary shown by the activity profile, an impact matrix is used as a checklist for the probable importance of the impacts under categories such as water supply, flood-prone areas, and water-contact recreation. These impacts are quantified either by a simple model or a more comprehensive and accurate one and are displayed on an impact profile showing the percentage change in a hydrologic characteristic versus distance downstream of the surface-mining site. The simple model for quantification considers only dilution from tributary areas during critical periods, whereas the comprehensive model routes flows and quality of water continuously through the year and considers, in addition to dilution, instream processes such as settling, biological uptake, and chemical reactions.
\end{abstract}

\title{
INTRODUCTION
}

\section{Purpose and Scope}

The purpose of this report is to present procedures for assessing the cumulative impact of coal mining on the hydrologic balance. Four steps were used to develop the procedure. First, a review was made of the appropriate sections of the Surface Mining Control and Reclamation Act of 1977 and the associated regulations so that the requirements for the assessments could be identified and the technical terms could be defined. Next, the technical literature was reviewed for evaluations and comparisons of methods for hydrologic analysis. Both simplified and comprehensive computer methods are reviewed. Third, available hydrologic methods were selected and a five-step procedure was developed. Fourth, the procedure was illustrated with a case study. 


\section{Legislative Requirements}

P.L. 95-87, Surface Mining Control and Reclamation Act of 1977, Sections $101(c)$ and $101(h)$, summarize the problems related to surface mining:

(c) "* * * many surface-mining operations result in disturbances of surface areas that burden and adversely affect commerce and the public welfare by destroying or diminishing the utility of land for commercial, industrial, residential, recreational, agricultural, and forestry purposes by causing erosion and landslides, by contributing to floods, by polluting the water, by destroying fish and wildlife habitats, by impairing natural beauty, by damaging the property of citizens, by creating hazards dangerous to life and property, and by degrading the quality of life in local communities and by counteracting governmental programs and efforts to conserve soil, water, and other natural resources * * *;"

(h) "* * * there are a substantial number of acres of land throughout major regions of the United States disturbed by surface and underground coal on which little or no reclamation was conducted, and the impacts from these unreclaimed lands impose social and economic costs on residents in nearby and adjoining areas as well as continuing to impair environmental quality * * *"

A principal purpose of the Act is to protect society and the environment from the adverse effects of surface coal-mining operations and minimize the adverse effect of abandoned mines. A permit program is established to regulate surface-mining operations, eventually to be enforced by the States. As part of the permit application and review procedures, determination of the probable hydrologic consequences is made by the operator or a qualified public or private laboratory (Sections $507($ b)(11) and $507(c)$ ). Of most concern herein, the approval of the permit requires as stated in Section $510(b)(3)$ :

"* * * the assessment of the probable cumulative impact of all anticipated mining in the area on the hydrologic balance specified in Section 507 (b) has been made by the regulatory authority and the proposed operation thereof has been designed to prevent material damage to hydrologic balance outside permit area $\star \star \star . " ~$

And prior to approval, the application for a permit must contain as stated in Section 507(b)(11):

"* * * a determination of the probable hydrologic consequences of the mining and reclamation operations, both on and off the mine site, with respect to the hydrologic regime, quantity and quality of water in surface- and ground-water systems, including the dissolved and suspended solids under seasonal flow conditions, and the collection of sufficient data for the mine site and surrounding areas so that an assessment can be made by the regulatory authority of the probable cumulative impacts of all anticipated mining in the area upon the hydrology of the area and particularly upon the water availability * * *." 


\section{Definitions}

Several key words and phrases used in the Act that have special significance are listed below, and each is discussed in the following sections:

- Hydrologic balance.

- Probable hydrologic consequence (determination).

- Probable cumulative impact (assessment).

- Material damage.

- General area.

- Disturbed area.

- Mine-plan area.

- Permit area.

Section 515(b)(10) under Environmental Protection Performance Standards requires the mining operation to minimize the disturbances to the hydrologic balance by avoiding acid or other toxic-mine drainage, preventing additional contributions of suspended solids to streamflow, restoring recharge capacity, avoiding channel deepening or enlargement, and preserving the essential hydrologic functions of the alluvial valley floors in arid and semi-arid areas of the country. Hydrologic balance then is a recognition that for a period of time the land and the climate are at a balance or equilibrium, and the balance in large part is achieved through (1) the vegetation that retards erosion and returns water back to the atmosphere and (2) the land and channel slopes that convey the excess water not used by the vegetation or recharged to a deeper aquifer. Hydrologic balance can be a useful concept and appropriate to legislation on regulation of surface mining since the impacts of surface mining are similar to urban development and conversions of land from forests to crops.

Watersheds in hydrologic balance undergo, for relatively long periods of time, very little change in vegetation, aquatic life, surface slopes and elevations, and channel slopes, sizes, and shapes. The natural meandering of channels in alluvial material, though changing more rapidly, is considered part of the balance. The impact from urban development is a good example of a watershed taken out of hydrologic balance. Basically, the increase in magnitude and frequency of floods from the addition of impervious surfaces causes severe erosion to downstream channels. Until the shift has been made to larger channels, possibly at different slopes, the watershed is not in hydrologic balance. Eventually, maybe within a few decades, the changes by natural processes will largely be complete and a new hydrologic balance achieved. The new hydrologic balance may or may not be more desirable. Generally, the conditions during the change from one balance to the next are less desirable. Another example of an activity that took watersheds out of hydrologic balance was the agricultural practices used on cotton plantations of the South; these caused severe land erosion and deposition of sediment in streams. Watersheds in parts of the South are still in the process of reaching a new balance.

The relation of the first four terms is found in Section 507 (b)(11) and Section $510(\mathrm{~b})(3)$. The determination of the probable hydrologic consequences is required so that an assessment of the probable cumulative impacts can be made. And the assessment determines whether there will be material damage because of changes in the hydrologic balance. 
Material damage as related to hydrology must be defined by the regulatory authority. Material damage depends strongly on local conditions. Increases in sediment load on a stream traversing an undeveloped area having little recreational value may have no damage at all while on another stream it may eliminate a sport-fish population. Though there is a wide range in damages as perceived by different people, it is rather clear that if a person or community receives a financial loss, material damage has occurred; if populations of a desired plant or animal species have been reduced substantially, material damage has occurred; or if stream channel banks continually erode on both sides of the channel or reservoirs fill with sediment, then material damage has occurred. Section 515, entitled "Environmental Protection Performance Standards," makes reference to "actual or potential threat of water diminuation or pollution" $(515(\mathrm{~b})(2))$, "prevent erosion and siltation, pollution of water, damage to fish or wildlife or their habitat, or public or private property" $(515(b)(17))$, and "minimize disturbances and adverse impacts of the operation on fish, wildiife, and related environmental values" $(515(b)(24))$. Though it is not the intent herein to define material damage or recommend specific stream standards, it is essential to address the issue because the goal of any quantitative method to assess cumulative impacts is to assist with decisions on whether there will be any material damage because of changes in the hydrologic balance.

Cumulative in the context of impact assessments has been interpreted as cumulative in time and cumulative in space. As used herein, cumulative in space refers to the cumulation of flows and dissolved or suspended matter from all mine-permit sites and land uses to common downstream channels. Cumulative in time refers, for example, to the gradual change in stream biota from a more acidic stream or the loss of reservoir capacity from sediment deposition. Some impacts take time to produce material damage.

Generally, cumulative will refer to the spacial cumulation of impacts of several permit areas being mined. Yet, some of those cumulative impacts also may cumulate in time.

One final group of terms are general area, disturbed area, mine-plan area, and permit area. For the purpose of this report, each is defined as follows, and they are listed from smallest to largest.

- Disturbed area.--Land where vegetation, topsoil, or overburden are removed or where topsoil, spoil, or waste products resulting from the operation are placed. Such land remains disturbed until it is reclaimed.

- Permit area.--Land and water within boundaries designated on the permit-application maps.

- Mine-plan area.--Land and water within boundaries of all permit areas during the entire life of the surface coal-mining and reclamation operations.

- General area.--Surface- and ground-water basins affected by or down gradient to the area of surface coal-mining and reclamation operations, the area of concern in the assessment of probable cumulative impacts. 
Thus, all permit areas are contained within a mine-plan area. And, all disturbed areas should be within a permit area. Only the general area, permit area, and disturbed area are used herein.

\section{Hydrologic Balance}

Hydrologic impacts from surface mining result largely from changes in (1) vegetation, (2) soils, (3) land configuration, and (4) the removal of coal aquifers. When vegetation is removed, 50 to 90 percent or more of the rainfall that was intercepted or transpired by the vegetation during a year becomes availahle for runoff, surface evaporation, or ground-water recharge. Typical distributions of annual rainfall found within five of the coal regions are shown on Table 1. A typical distribution for the Eastern Coal Region, Interior province, is illustrated in Figure 1.

Table 1.--nistribution of annual rainfall.

\begin{tabular}{|c|c|c|c|c|c|c|}
\hline $\begin{array}{c}\text { Coal } \\
\text { Province } \\
\end{array}$ & $\begin{array}{c}\text { Coal } \\
\text { Region } \\
\end{array}$ & State & $\begin{array}{l}\text { Annual } \\
\left\{\begin{array}{l}\text { ainfal1 } \\
\text { (in) }\end{array}\right.\end{array}$ & $\begin{array}{l}\text { Annual } \\
\text { Runoff } \\
\text { (in) }\end{array}$ & $\begin{array}{l}\text { Annual } \\
\text { ET (in) }\end{array}$ & $\begin{array}{c}\text { ET as a } \\
\text { Percent of } \\
\text { Rainfall }\end{array}$ \\
\hline Eastern & Appalachian & W. Virginia & 48 & 20 & 28 & $58 \%$ \\
\hline Interior & Eastern & Illinois & 40 & 10 & 30 & $75 \%$ \\
\hline Interior & Western & Kansas (eastern) & 35 & 7 & 28 & $80 \%$ \\
\hline Interior & Southwestern & Texas (eastern) & 30 & 5 & 25 & $83 \%$ \\
\hline $\begin{array}{l}\text { Northern } \\
\text { Great } \\
\text { Plains }\end{array}$ & Fort Union & North Dakota & 16 & 1 & 15 & $94 \%$ \\
\hline $\begin{array}{l}\text { l'Linsley } \\
\text { Enginee }\end{array}$ & $\begin{array}{l}\text { Ray K., Jr. } \\
\text { s," McGraw-Hi }\end{array}$ & $\begin{array}{l}\text { ohler, Max A., ar } \\
\text {, } 1975 \text {. }\end{array}$ & and Paulh & $S, J \cdot L$. & ., "Hydrc & logy for \\
\hline
\end{tabular}

The substantial impact of vegetation on the hydrologic balance usually is underestimated. Often to assess impacts, storm hydrograph analysis is done that is based solely on changes in infiltration rates. Unfortunately, such analyses seldom consider the cumulative effects in time of no transpiration losses causing higher soil-moisture conditions a few inches below the surface. And, soil-moisture differences often have a greater effect on infiltration than variation in soil characteristics. That is, the difference in infiltration rates between a clayey loam and sandy loam can be much less than a wet clayey-loam soil and a dry clayey-loam soil. Another impact of removing vegetation is packing the soil from the kinetic energy of raindrops which decreases infiltration rates. Vegetation also retards overland flow velocities providing more time for infiltration to occur, and the growth and decay of roots tend to increase infiltration. 


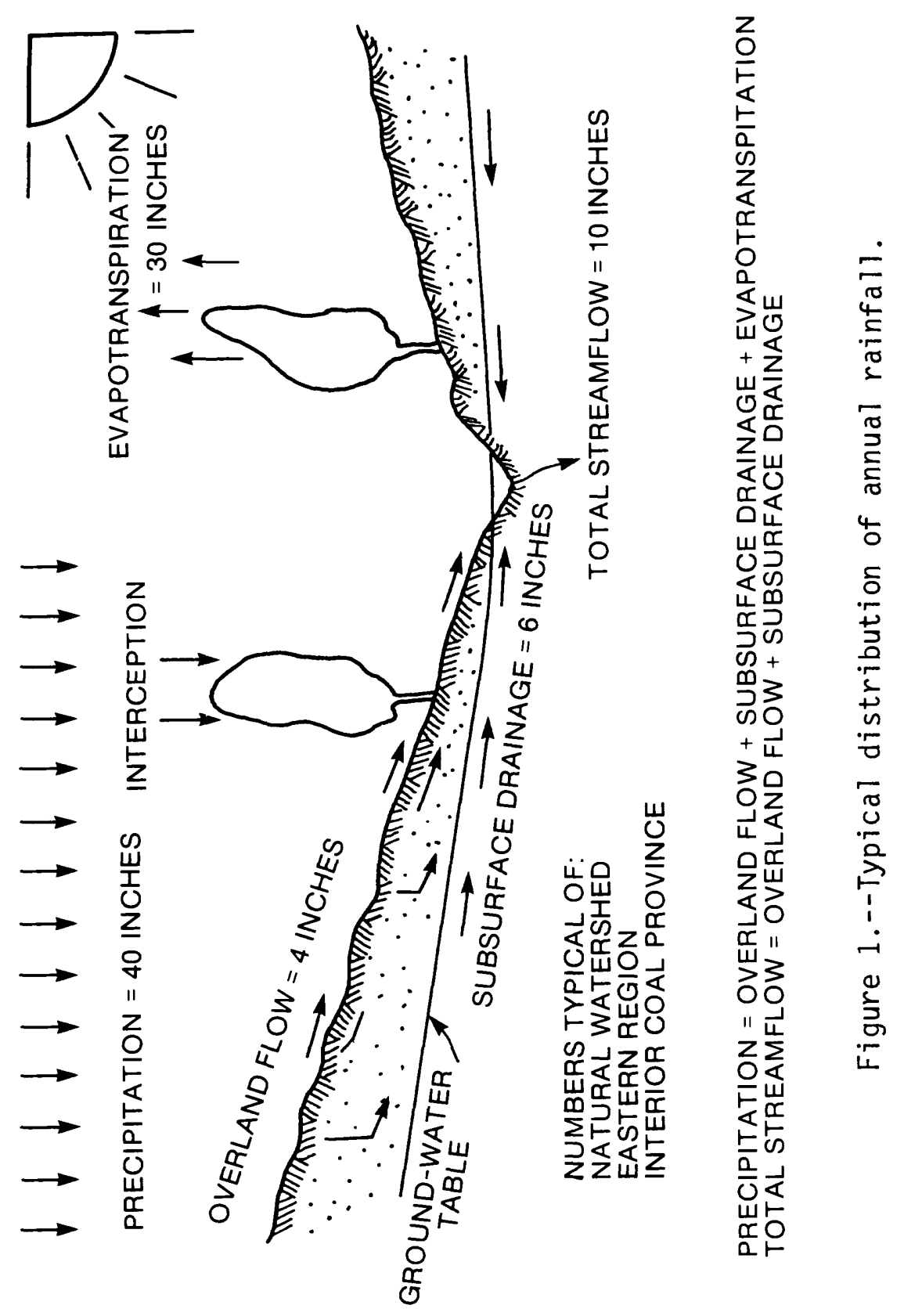


When vegetation is removed, the distribution of the rainfall that is no longer intercepted or transpired depends on the soil moisture, amount of packing from rolling equipment and raindrop impact, alterations to surface slope, addition or elimination of surface depressions, amount of terracing and erosion-control measures, and construction of berms and other flow-diversion facilities. Any of these factors can cause an increase or a decrease in overland flow, subsurface seepage, or recharge to deep aquifers, but the net change on these three must be an increase in available water since transpiration losses are greatly diminished or eliminated. Thus, with flatter slopes, berms and more surface depressions, overland flow for disturbed surfaces during surface coal mining might decrease, but ground-water recharge to deep aquifers or seepage or surface evaporation would increase. If very little is done to the land surface except removal of vegetation, much of the decrease in transpiration will result in an increase in overland flow.

If overland flow increases from the removal of vegetation, the sediment load is most likely to increase. Even if overland flow does not increase, sediment loads may still increase from the lack of vegetation. However, the production and transport of sediment may be reduced by such measures as covering the soil surface with mulch, substantially reducing the land slopes, and constructing and maintaining sediment detention ponds.

Ground-water recharge in many cases is likely to increase since the soil moisture, except for the first few inches at the surface, will remain near field capacity. This condition is likely to occur since the upward migration of soil moisture to the surface for evaporation proceeds much slower than moisture depletions by transpiration. Thus, very little of the rain that infiltrates will be needed to replenish the soil moisture and excess water will percolate down to the water table. In watersheds in the eastern and central coal provinces the major effect on ground water will be detected in the perched water tables that discharge to streams with retention times of only a few months to a year. If these shallow aquifers are not excavated, compacted, or blocked from their normal drainage, they are likely to receive, store, and discharge a greater volume of water to the streams.

Overburden removal and replacement operations may create perched water tables where none existed before. This could occur when rock of very low storage and permeability is replaced with unconsolidated material. Removal of overburden and coal also can provide quicker drainage of existing nearsurface aquifers, causing water levels in the immediate area to decline.

Potentially, a major impact of overburden removal and replacement in addition to sediment production is the exposure of new material to percolating water and the subsequent increase in dissolved solids.

\section{Material Damage}

Material damage to the hydrologic balance or impacts of mining upon the hydrology of the area, as stated in the Act, includes changes in quantity of water, quality of water, and sediment yield, all under seasonal-flow conditions. All surface mining causes some change in the hydrology of the permit area and of the general area; and any issuance or denial of a permit must be based on an assessment of the consequences of each permitted mine and all 
anticipated mines in the general area. Three equally complex tasks arise when assessing impacts: (1) quantifying the impacts at each permit area, (2) cumulating the impacts downstream; and (3) defining material damage. The most accurate and sophisticated computer models on hydrology are of no value to the permit process unless, for example, a change in sediment concentration, or a change in the average annual low flow and water temperature, or a change in $\mathrm{pH}$ is at least qualitatively related to material damage.

Although several possibilities for identifying material damage are outlined herein, material damage must be determined by the regulatory authority by identifying water uses and the acceptable level of impact. One consideration, though seldom practical, is confining the impacts to the permit area. If the water leaving the permit area is the same as would have occurred with no mining activities, then impacts would not exist. Often construction of detention ponds leads one to believe the impact will be zero. Yet, this is not the case. Sediment ponds do not remove all dissolved solids and claysized particles. Ponds can alter water temperature. And ponds are often not constructed and maintained as designed. Studies in urban areas (Lumb, 1974) showed the cumulative impacts of all developments increased flooding even with detention basins at each development. Thus, control measures on the permit area may decrease the severity of impacts but are not likely to eliminate them.

Material damage in the general area might occur to current or potential water uses such as water-contact recreation, fishing, water-supply quantity and quality, navigation, wildlife preservation, hydroelectric power and cooling water. High concentrations of sediment are detrimental to aquatic life, reduce storage capacity of reservoirs, and increase water purification costs. Acidic waters also are detrimental to aquatic life and can damage diversion and conveyance works. Greater storm runoff magnifies damages especially if accompanied by higher sediment concentrations and streambank erosion. The latter is a common occurrence in rapidly developing urban areas, where bank erosion undercuts the trees which fall into and clog the channel which can further increase flood levels and can divert flows which may even erode a new channel. This process may continue for decades until new or larger channels have evolved and a new hydrologic balance is reached.

Although costs in dollars to the downstream environment and water users in the general area would be very useful in determining material damage and managing cumulative impacts, such cost estimates are difficult to develop. Current state of the art in hydrology, aquatic biology, and natural resource economics have some capabilities to make cost estimates, but it has not been translated into a usable methodology. Thus, estimates of material damage can not be based on cost estimates and as a substitute must be based on changes in the physical and chemical properties of the water in the general area. Given stream standards which indirectly, or in a few cases directly, relate to material damage, a comparison can be made between the standards and the estimate of conditions before and after mining permits are issued. Thus, if the stream standard for $\mathrm{pH}$ is 6.0 and the increased acidity from tributary streams with surface mining causes the $\mathrm{pH}$ during the average annual 7 -day low-flow period to change from 6.3 to 5.8 , then material damage can be defined to have occurred, or if a violation of drinking water standards for ground-water supplies is attributable to mining, the material damage has occurred. 
One very important aspect in defining stream standards is probability. If the standard is not applicable to all conditions all of the time, which would be extremely expensive to achieve and enforce, then probabilities must be considered. For example, a standard might state that the pH must be between 6.0 and $9.0,99$ percent of the time, or temperature during low flows in August and September may exceed $28^{\circ} \mathrm{C}$ for only 4 hours on the average once in 10 years. These are probability statements of standards. Needed for cumulative impact assessments are probability statements of stream standards that protect the general area from material damage. Establishing standards is a difficult task but (1) must be done; (2) al ready has been done to a limited extent as evidenced by water-quality standards for each State stream classification, water rights, interstate and international compacts, and water rights on Indian lands; and (3) is a necessary part of the methodology described herein.

\section{Cumulative Impact Techniques}

Techniques for estimating cumulative impacts must produce outputs that can be used for comparison with stream standards so that a decision to issue or deny the permit can be made. These outputs may include high and low frequencies of occurrence under seasonal conditions for flow, dissolved solids, heavy metals, suspended solids, and pH. Most often these outputs will be required at points in complex drainage networks which include not only surface mining, but also (1) underground mining; (2) impoundments; (3) impacts from urban lands and lands being logged, cultivated, and grazed; and (4) diversions of flow to and from the streams. Additional requirements or constraints on needed techniques are (1) the personnel and expertise available; (2) time and funds; and (3) computer hardware and software.

Hydrologic techniques for defining cumulative impacts fall in one of two categories: (1) statistical or graphical correlation, and (2) mathematical modeling of processes. Statistical correlations have been developed for similar analyses such as impacts of urban development, yet the correlations often lack the cause/effect relations needed to assess cumulative impacts. To develop correlations, more information is required than currently exists. Many types of water-quantity and quality data, for many land uses, for many drainage area sizes, with many different soils, and many control measures, over all seasons, for many years, would be required to develop correlations useful in cumulative impact assessment. The effects of size and location of impoundments, diversions for water supply and waste discharges, and complex drainage networks are not even considered. Correlation analysis, however, is useful in adjusting local data to get a rough approximation of flow frequencies and associated pollutant concentrations and can be useful in the hydrologic determination for a permit area.

The second technique is mathematically simulating the essential physical processes, a complex technique requiring much more expertise, time, data, and funds than application of statistical correlations. Yet, as we have taken a complex machine as the automobile and reduced its utilization to a pedal for going, a pedal for stopping, and a wheel for turning, mathematical simulation with good design and digital computers can reduce the expertise required for adequate operation. This point cannot be made too strongly because users of models continue to state the need for a model that is "simple and easy to use" 
when they only need to say "easy to use." However, mathematical simulation takes time and funds. Other local and Federal agencies dealing with similar problems such as cumulative impacts of urban development or pesticide applications have decided the severity of the problem justifies the cost and effort.

\section{GUIDELINES AND MATRIX}

\section{General Approach}

The general approach to the hydrologic assessment of cumulative impacts of surface coal mining is summarized in Figure 2. Five steps are included:

(1) Have regulatory authority assign stream standards or other physical/ chemical/biological criteria.

(2) Develop a hydrologic activity profile to help select levels of potential impact for each category of material damage.

(3) Mark the estimated level of potential impact on the impact matrix.

(4) Quantify the changed physical, chemical, or biological characteristics and compare them with those before mining and with established stream standards.

(5) Make a decision on the permit.

The five steps are discussed below.

\section{Water-Quality Standards and Criteria}

Each State has developed a stream-classification system with waterquality standards for each class of stream. Generally, streams classified for water-contact recreation and municipal water supplies have the highest standards while streams classified for industrial use have the lowest standards. Parameters usually included are dissolved oxygen, temperature, $\mathrm{pH}$, and BOD. Acidity, suspended sediment, dissolved solids, sulfate, and heavy metals often are not included. If the parameters important to surface mining are not included, the regulatory authority may establish a standard for each based on the State's stream-classification system.

\section{Hydrologic Activity Profile}

A hydrologic activity profile of a stream is a graph of cumulated drainage area versus distance along the channel from the mine site. The graph includes the location of diversions, return flows, and reservoirs. As water and the dissolved and suspended matter flow from the permit area and travel down the drainage network, the negative impacts are most always diminished by (1) instream physical, chemical, and biological processes such as biological uptake, settling, absorption on sediment particles, and chemical reactions, and (2) dilution as tributary streams join the drainage network. At some point downstream, which could be all the way to the ocean, material damage may no longer occur. Instream processes and dilution can be quantified with routing 


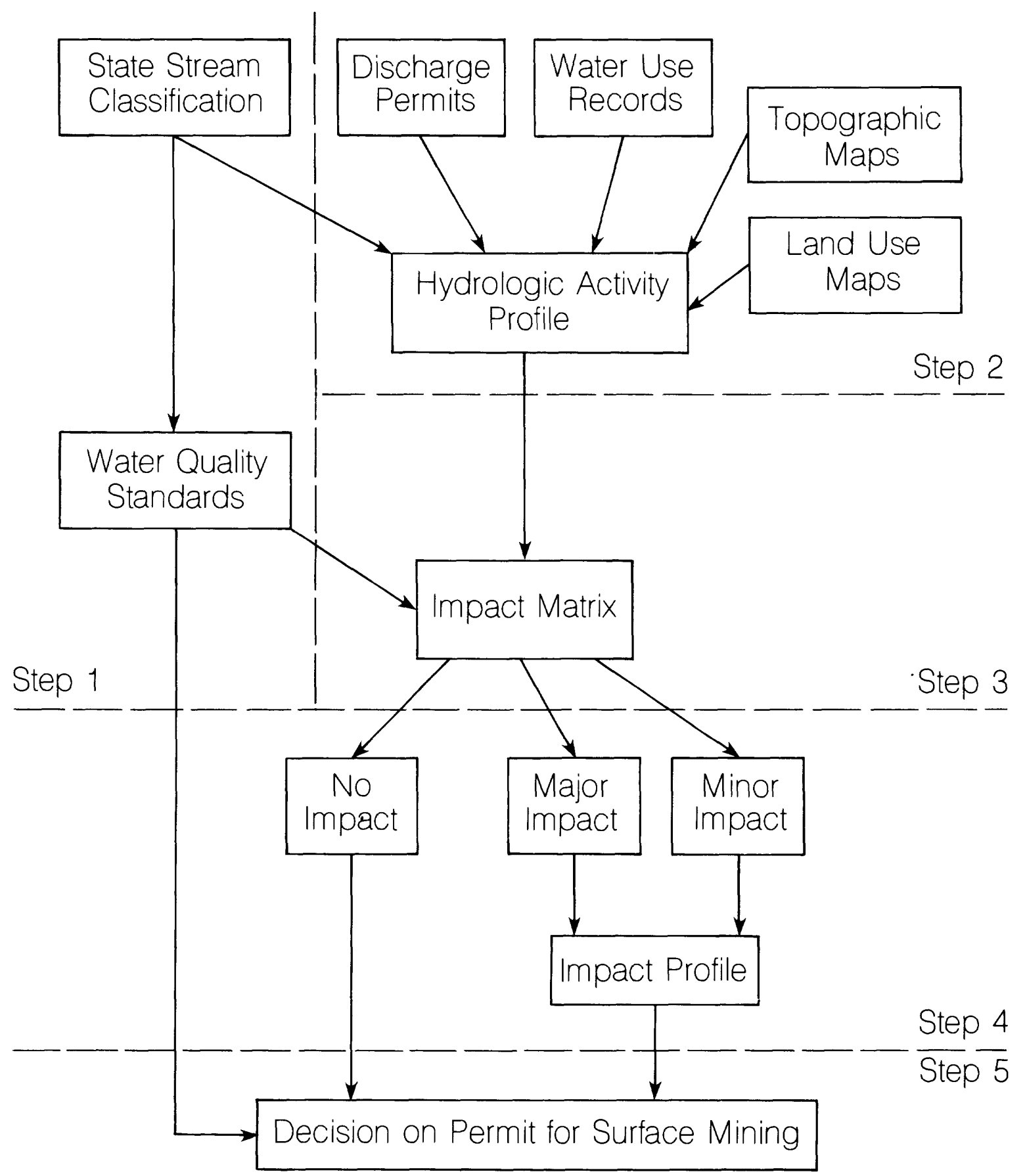

Figure 2.--Steps for a cumulative impact assessment. 
models or simple adjustments as discussed in the next section. But first, a hydrologic activity profile must be drawn. Important land and water uses would be identified such as water-supply intakes, points of discharge from sewage-treatment plants, reservoirs, trout streams, flood plains that could incur significant damages or loss of life during floods, and sections designated as wild or scenic rivers or along parks.

Activity profiles can be developed directly from topographic and landuse maps of the drainage basin. At selected points downstream from the permit area, stream mileage is noted and drainage area measured. The values are then plotted. Figure 3 is an example of an activity profile for the Tug Fork basin in Kentucky and West Virginia. A logarithmic scale for the vertical axis is useful since drainage area is often a power function of stream length.

\section{Impact Matrix}

Once an activity profile is developed and stream standards are established for the drainage basin, a subjective cataloging of the potential impacts can be done using the impact matrix (Table 2). The impact matrix is a checklist for potential downstream impacts from the permit areas. On the matrix, columns can be marked as potentially no impact, minor impact, or major (critical) impact. That judgment, then, determines the depth of analysis required. In making the judgments, four main factors should be considered:

(1) Use of the streams below the permit area.

(2) Distance downstream as reflected by cumulative drainage area (the greater the cumulated area, generally, the greater the dilution).

(3) Stream classifications such as sport fisheries or industrial.

(4) Current flow and quality conditions of the stream.

\section{Quantifying Impacts}

\section{No Impact}

Many cases may exist where water-supply intakes, contact recreation, etc. are located downstream of the mining area at points that drain areas many times greater than the potential or existing areas to be mined. When the drainage area at the point of water use is several orders of magnitude greater than that at the mined area, then that mine should cause no material damage to the water supply since the physical/chemical constituents in the water from the mined area would be greatly diluted. Conversely, if inputs from other mining or land uses from contiguous watersheds were occurring, they would increase the chances for material damage to occur. Conceivably, one more mine might cause a standard to be exceeded and be cause for denying a permit.

The hydrologic activity profile can be used as a very simplistic screening procedure. As the drainage area increases several orders of magnitude greater than the total of the permit areas, that drainage area can be marked on the activity profile to identify a point below which material damage would no longer occur. 


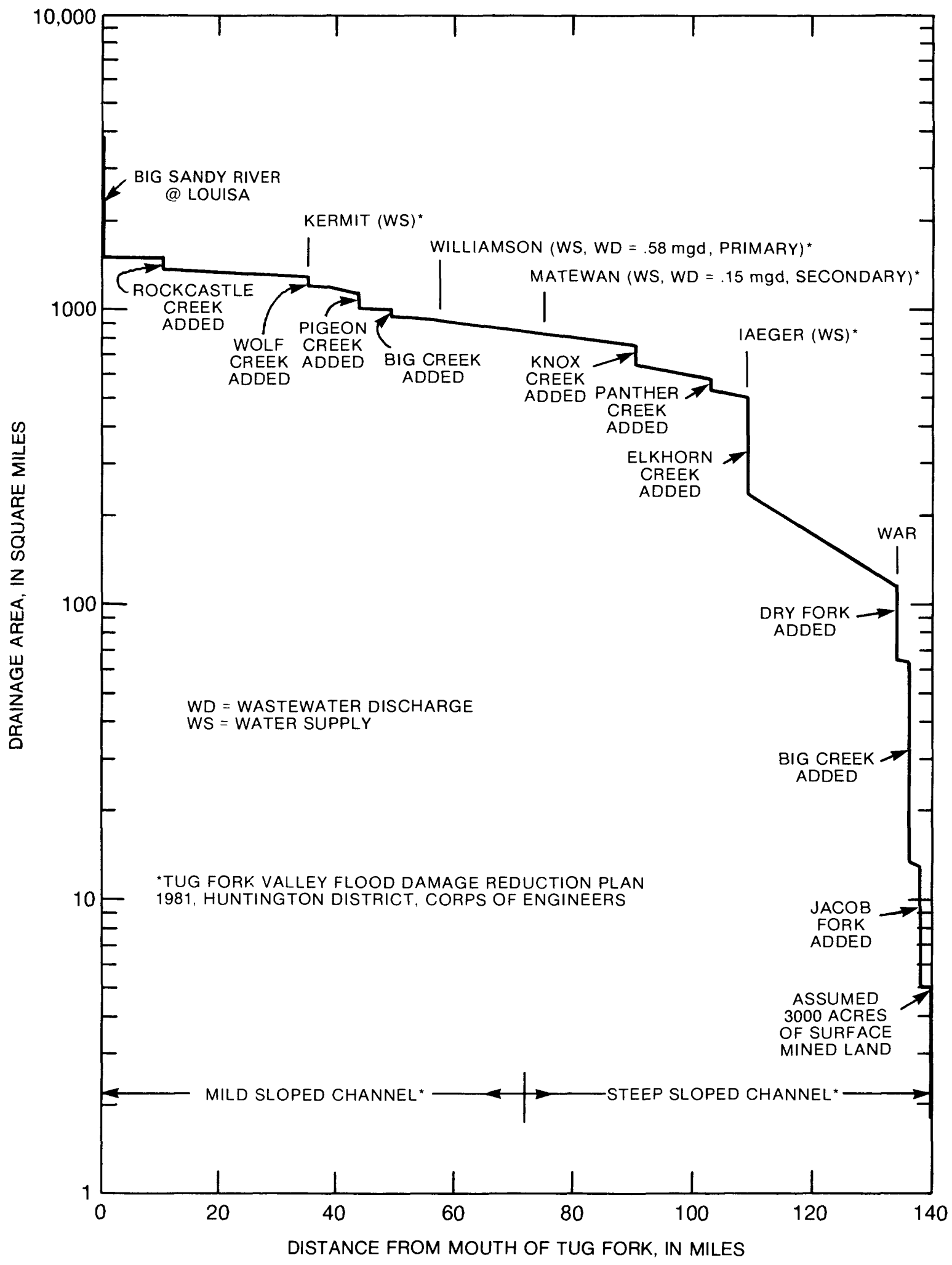

Figure 3.--Hydrologic activity profile, Tug Fork, W. Va. 
Table 2.--Impact matrix.

\begin{tabular}{|c|c|c|c|c|c|}
\hline \multirow[b]{2}{*}{$\begin{array}{c}\text { Material } \\
\text { Damage }\end{array}$} & \multirow[b]{2}{*}{$\begin{array}{l}\text { Physical-Chemical } \\
\text { Characteristics }\end{array}$} & \multirow[b]{2}{*}{$\begin{array}{l}\text { Stream Standards } \\
\text { or Other Criteria* }\end{array}$} & \multicolumn{3}{|c|}{$\begin{array}{c}\text { Checklist for } \\
\text { Impacts Based on Degree of } \\
\text { Impact** }\end{array}$} \\
\hline & & & $\begin{array}{c}\text { no } \\
\text { impact }\end{array}$ & $\begin{array}{l}\text { minor } \\
\text { impact }\end{array}$ & $\begin{array}{l}\text { major } \\
\text { impact }\end{array}$ \\
\hline \multirow{6}{*}{$\begin{array}{l}\text { WATER SUPPLY } \\
\text { Surface Water } \\
\text { Streams }\end{array}$} & Low f low & & & & \\
\hline & Stage & & & & \\
\hline & Alkalinity, acidity, $\mathrm{pH}$ & & & & \\
\hline & Suspended solids & & & & \\
\hline & Heavy metals & & & & \\
\hline & Salts & & & & \\
\hline \multirow{6}{*}{$\begin{array}{l}\text { Surface Water } \\
\text { Reservoirs }\end{array}$} & Flow (yield) & & & & \\
\hline & Stage & & & & \\
\hline & Alkalinity, acidity, $\mathrm{pH}$ & & & & \\
\hline & Suspended solids & & & & \\
\hline & Heavy metals & & & & \\
\hline & Plankton & & & & \\
\hline \multirow[t]{3}{*}{ Ground water } & Water level & & & & \\
\hline & Porosity (storage) & & & & \\
\hline & Leachate & & & & \\
\hline \multirow{5}{*}{$\begin{array}{l}\text { FLOOD PRONE } \\
\text { AREAS }\end{array}$} & Flood frequency & & & & \\
\hline & Stage & & & & \\
\hline & Suspended solids & & & & \\
\hline & Velocity & & & & \\
\hline & Channel configuration & & & & \\
\hline \multirow{5}{*}{$\begin{array}{l}\text { WATER-CONTACT } \\
\text { RECREATION } \\
\text { Boating, } \\
\text { swimming, } \\
\text { fishing }\end{array}$} & Depth and stage & & & & \\
\hline & Velocity & & & & \\
\hline & Suspended sediment & & & & \\
\hline & Heavy metals & & & & \\
\hline & Alkalinity, acidity, $\mathrm{pH}$ & & & & \\
\hline \multirow{12}{*}{$\begin{array}{l}\text { AQUATIC LIFE, } \\
\text { plankton, } \\
\text { benthos, } \\
\text { fish, } \\
\text { Aquatic and } \\
\text { riparian } \\
\text { vegetation }\end{array}$} & Depth and Stage & & & & \\
\hline & Water surface area & & & & \\
\hline & Channel configuration & & & & \\
\hline & Velocity & & & & \\
\hline & Temperature & & & & \\
\hline & Alkalinity, acidity, $\mathrm{pH}$ & & & & \\
\hline & Light transmissivity & & & & \\
\hline & Heavy metals & & & & \\
\hline & Suspended solids & & & & \\
\hline & Bed material & & & & \\
\hline & \begin{tabular}{|l|} 
Salts \\
\end{tabular} & & & & \\
\hline & Flood frequency & & & & \\
\hline \multirow[t]{3}{*}{ NAVIGATION } & Velocity and depth & & & & \\
\hline & Suspended solids & & & & \\
\hline & Acidity, $\mathrm{pH}$ & & & & \\
\hline \multirow{3}{*}{$\begin{array}{l}\text { RYYDROELECTRIC } \\
\text { POWER }\end{array}$} & Flow & & & & \\
\hline & Suspended solids & & & & \\
\hline & Acidity, $\mathrm{pH}$ & & & & \\
\hline
\end{tabular}

*To be established by Regulatory Authority

**Based on impact profile 
For ground water, dispersion is the process that dilutes the dissolved constituents. And, with distance from the disturbed area, the damage may become minimal. Understanding the ground-water flow paths is necessary to determine if there is potential impact. If the ground water discharges to a stream before it is used, then the surface-water impact profile can be used. If the distance is sufficient for adequate dispersion, then the no-impact column on Table 2 could be checked. Unfortunately, adequate dispersion is very difficult to define as is identification of flow paths.

\section{Minor Impact}

If the no-impact column on Table 2 cannot be checked, then analysis for minor or major impact must be done. Usually the activity profile can be used to make the distinction. Obviously, surface mining 2 miles upstream of trout water could constitute a major impact while a flood-prone area 60 miles downstream may only present a minor impact. When in doubt, a minor impact analysis should be done and that should suggest whether a major impact analysis is needed.

Since only in a few limited areas have equations for hydrologic impacts of a given mining operation been developed, a simple procedure is recommended using (1) the disturbed area for the current permit, (2) other areas in the same drainage basin currently permitted, not fully reclaimed, and anticipated for future mining, and (3) the total drainage area at key points along the activity profile. This procedure described below is general and could apply to any area. However, any equations developed specifically for the area of interest should be used instead of the general procedure. One example is an equation for specific conductance in the Warrior coal field in the Southern Appalachian Coal Region. In that case, specific conductance was related to average discharge per square mile, percent of the area disturbed, stream distance from the mine, and a mine-age factor (Puente, 1981).

The hydrologic evaluation submitted with a permit application provides estimates of the changes in the quantity and quality of water from the permit area under seasonal flow conditions. General area hydrology reports provide data or estimates of many hydrologic conditions. From these data, estimates can be made by the regulatory authority to assess impacts using the techniques outlined below.

Low Flow

Low-flow estimates for critical points on the impact profile can be made using regional low-flow equations or by making an analysis of the data from a nearby stream gage and making adjustments based on drainage area.

where

$$
Q_{c}=Q_{g} \frac{A_{c}}{A_{g}}
$$

$$
\begin{aligned}
Q_{c}= & \text { low-flow statistics at a critical point on the hydrologic activity } \\
& \text { profile before permit area operations begin, } \\
Q_{g}= & \text { low-flow statistics at a nearby stream gage, }
\end{aligned}
$$


$A_{c}=$ drainage area above critical point, and

$A_{g}=$ drainage area above the nearby gage site.

The percent change in the low-flow statistic $(P)$ is

$$
P=100 \frac{D_{1 f}}{Q_{C}}
$$

where

$$
\begin{aligned}
D_{1 f}= & \text { estimated change in the low-flow statistics from the required } \\
& \text { hydrologic evaluation of the permit area, }
\end{aligned}
$$

and the impacted statistic, $Q_{n c}$, at the critical point is

$$
Q_{n c}=Q_{c}+D_{1 f} \text {. }
$$

Often equations for low-flow statistics that are applicable to States or river basins have large standard errors and adjusting data from a nearby gage with equation (1) could provide a more accurate estimate if the drainage areas are influenced by the same climate and geology and are close to the same size. Occasionally, there will be a few low-flow measurements at the critical point or a few measurements could be made. These measurements could be used to develop an intergage correlation which could then be used to make adjustments to the data. That is, the flow characteristics at the stream gage with a long record could be used in the intergage correlation to get an estimate of the flow characteristics at the stream gage with a short record.

\section{Flood Frequency}

Flood-frequency impacts can be handled the same as low flow. Equations are available for all coal-mining areas and are presented in the U.S. Geological Survey (USGS) series of Coal Area Reports as well as USGS State reports on flood frequency. The percent change in the floodflow statistic ( $P$ ) would be

$$
P=100 \frac{D_{f f}}{Q_{c}}
$$

where

$$
\begin{aligned}
D_{f f}= & \text { estimated increase in the flood-frequency statistic from the } \\
& \text { required hydrologic evaluation of the permit area, } \\
Q_{c}= & \text { flood-frequency statistic at a critical point on the hydrologic } \\
& \text { activity profile before permit area operations begin, }
\end{aligned}
$$

and the impacted statistic at the critical point is

$$
Q_{n c}=Q_{c}+D_{f f} \text {. }
$$




\section{Stage/Surface Area/Velocity}

Whether for low flow and the effect on aquatic life and water supplies or high flow and the effect on flood damages, the change in stage, velocity, and surface area can be estimated from the change in flow and rating curves. Graphs or tables of stage versus discharge, stage versus surface area, and stage versus velocity are available at stream-gage sites or can be computed from channel cross sections, roughness, and slope.

\section{Salts and Heavy Metals}

Constituents for a minor impact analysis are treated as conservatives. Heavy metals and salts are usually critical during dry weather flow but potentially could be critical during the recession of a storm hydrograph. Only the analysis recommended for major impact can address the potential problem during the recession of the storm hydrograph.

Estimated concentrations of heavy metals and salts are needed for the general area and for the permit area. With the proposed surface mining the new concentration at a critical point is

$$
C_{n c}=\frac{Q_{p} C_{p}+Q_{c}\left(\frac{A_{c}-A_{p}}{A_{c}}\right) C_{g}}{Q_{p}+Q_{c}\left(\frac{A_{c}-A_{p}}{A_{c}}\right)}
$$

where

$C_{n c}=$ new concentration at the critical point,

$C_{g}=$ concentration from the general area,

$C_{p}=$ concentration from the permit area,

$A_{C}=$ drainage area above the critical point,

$A_{p}=$ permit area in the drainage basin,

$Q_{p}=$ flow from the permit area in the drainage basin, and

$Q_{c}=$ flow at the critical point before permit area operations begin.

These mass-balance estimates are appropriate for the salts which are not likely to precipitate. Heavy metals may adsorb on sediment particles which may settle and not reach downstream critical points or may be reduced by biological uptake. Equation (6), then, is likely to overestimate the concentration of heavy metals.

Suspended Sediment

Equation (6) also can be used to obtain a rough estimate of the mining impact on sediment. However, sediment load instead of sediment concentration 
may be a more practical measure. For sediment loads, sediment delivery ratios should be used to determine the amount of sediment leaving a permit area that reaches a downstream point. Based on data developed by Roehl (1962) and Brandt, et al. (1972) and presented by Chen (1974), a sediment delivery ratio representing the worst case is

$$
\begin{array}{ll}
R=1.0 & A_{C} \leq 0.1 \mathrm{sq} \mathrm{mi} \\
R=0.7 A_{C}-0.155 & A_{C}>0.1 \mathrm{sq} \mathrm{mi}
\end{array}
$$

where

$$
A_{C}=\text { drainage area above critical point (sq mi). }
$$

The equation is based on data from the Piedmont physiographic area of Georgia and North and South Carolina, sand-clay hills of Mississippi, Blackland Prairies of Texas, loess hills of Iowa and Nebraska, and Red Hills of Texas and Oklahoma. Thus, using equation (7) only 34 percent of the sediment load from a permit area would reach a downstream point draining 100 square miles. Applying equation (7) gives

where

$$
L_{n c}=L_{c}+0.7 A_{c}-0.15 n_{s}
$$

$L_{n c}=$ new sediment load at the critical point,

$L_{c}=$ sediment load at the critical point before permit area operations begin,

$A_{C}=$ drainage area above critical point, and

$D_{S}=$ change in sediment load from the permit area.

Sediment delivery downstream can be further reduced by major reservoirs. In such cases a trap efficiency for the reservoir can be used based on reservoir capacity, annual inflow, and sediment size (Brune, 1953). Values of 90 percent are used for capacities exceeding 30 percent of the annual inflow. For smaller capacities

$$
\begin{array}{ll}
T=90 & \text { for } S \geq 0.3 \\
T=113+19 \ln (S) & \text { for } S<0.3
\end{array}
$$

where

$$
\begin{aligned}
& T=\text { trap efficiency, in percent, } \\
& \ln =\text { natural logarithm, base e, and } \\
& S=\text { reservoir capacity/annual volume of inflow, acre-ft/acre-ft. }
\end{aligned}
$$

Given the sediment load to the reservoir from equation (8), the sediment load leaving the reservoir would be 


$$
L_{n c}^{\prime}=(1-T / 100) L_{n c}
$$

where

$$
\begin{aligned}
& L_{n}^{\prime} c=\text { new sediment load below the reservoir, tons, } \\
& L_{n c}=\text { new sediment load entering the reservoir, tons, and } \\
& T \quad=\text { trap efficiency, percent. }
\end{aligned}
$$

Summary

Definitions of the terms in the equations above are:

$\underline{\text { Variable }}$

D - change from permit area

Q - flow statistic

C - quality of water statistic, concentration

$P$ - percent change

A - drainage area

$L$ - sediment load

$R$ - sediment delivery ratio

$T$ - reservoir trap efficiency
Subscript

If - low flow

ff - floodflow

q - quality of water

s - sediment load

p - permit area

c - original statistic at critical point

g - general area

nc - new statistic at critical point

Information to be supplied by the hydrologic evaluation as part of the permit application includes:

Dif - change in low flow from permit area.

Dff - change in floodflow from permit area.

$C_{p}$ - quality of water statistics from the permit area.

$D_{q}$ - change in quality of water statistic from the permit area.

$D_{S}$ - change in sediment load from the permit area.

Ap - permit area in the drainage basin being analyzed.

Information supplied by the regulatory authority for the cumulative impact assessment includes: 
$0_{c}$ - flow statistics at the critical point.

$C_{g}$ - quality of water statistic for the general area.

$A_{C}$ - drainage area above critical point.

$S$ - ratio of reservoir capacities to annual inflows for reservoirs in the drainage area.

Information to be computed includes:

$P$ - percent change in statistics at a critical point with permit approval.

Qnc - flow statistic at a critical point with permit approval.

$C_{n c}$ - quality of water statistic at a critical point with permit approval.

$L_{n c}$ - sediment load at a critical point with permit approval.

R - sediment delivery ratio.

T - reservoir trap efficiency.

A microcomputer could be used to organize the data, make the computations for the minor impact analysis, plot the activity profile, and print a table of values at each critical point.

Major Impact

When a minor impact analysis indicates material damage may be done, or professional judgment indicates that a definite potential for material damage exists, then a major impact analysis should be conducted. Such analysis involves routing flow and physical-chemical characteristics down the drainage network. Several hydrologic models programed for the digital computer are available for this level of cumulative impact analysis. Routing models should include the effects of the instream physical, chemical, and biological processes as well as dilution. Input needed from the hydrologic evaluations of the permit area are much different for the routing models than the simplified procedures of the minor impact analysis.

Models

Several models for routing the quantity and quality of water are available (Jennings et al. (1980), Brown et al. (1974)). A useful division of available models is short-term or event simulation and long-term simulation. The requirements of the Act for seasonal analysis and high-and low-flow analysis greatly reduce the utility of event models which only route during a short critical period of time. A major shortcoming of the event models, which are either designed for dry-weather flow conditions or storm conditions, but seldom both, is that they do not simulate the cumulative effects of rainfall and evapotranspiration on soil moisture as discussed earlier or cumulative 
effects on pollutant buildup, lake levels, and streamflows. The group of routing models that continuously simulate hydrologic variables is smaller and includes:

\begin{tabular}{|c|c|c|}
\hline Model & Supporting Agency & Reference \\
\hline $\begin{array}{l}\text { CREAMS (Chemical, Runoff and } \\
\text { Erosion Agricultural Management } \\
\text { System) }\end{array}$ & $\begin{array}{l}\text { SEA, USDA (Science and } \\
\text { Education Administration, } \\
\text { U.S. Department of } \\
\text { Agriculture) }\end{array}$ & Knisel (1980) \\
\hline $\begin{array}{l}\text { HYSIM (Hydrologic Program for } \\
\text { Quantifying Land-llse Change } \\
\text { Effects) }\end{array}$ & $\begin{array}{l}\text { TVA/EPA (Tennessee Valley } \\
\text { Authority, Environmental } \\
\text { Protection Agency) }\end{array}$ & Betson (1980) \\
\hline $\begin{array}{l}\text { HSPF (Hydrologic Simulation } \\
\text { Programing--Fortran) }\end{array}$ & EPA/USGS & Johanson (1980) \\
\hline $\begin{array}{l}\text { PRMS (Precipitation-Runoff } \\
\text { Modeling System) }\end{array}$ & USGS & Leavesley (1981) \\
\hline
\end{tabular}

Two other models developed at Ohio State (Schumate, 1976) and Arizona State (Berkas, 1978) also can simulate conditions continuously for long periods but lack the documentation, support, or validation. CREAMS and HYSIM simulate continuously but have no ability to route flows down the drainage network. They only have utility for the hydrologic evaluation of a permit area. PRMS simulates flows and sediment but no chemical characteristics. HSPF generates overland and subsurface flow and over 15 physical-chemical characteristics and routes each downstream. There also exists several water-quality models that route flows and physical-chemical characteristics but have no capacity to generate runoff and pollutants from the land. Coupling models such as CREAMS with a dynamic stream water-quality model is possible but most likely would be difficult to use. TVA HYSIM and PRMS may be a little easier to use than HSPF but offer less flexibility. Current software development efforts by the USGS and EPA are making the interface between user and model for the HSPF system much easier and the added software is planned for release by spring of 1982.

With its structured program design, the HSPF model can be loaded on smaller computers; however, HSPF will take more computer processing time. Except for minor variations between systems for direct access files, the Fortran used is standard. PRMS uses an indexed sequential file system and though programed in Fortran has some support modules in PL/1. HYSIM uses sequential files and Fortran. HSPF has been loaded and tested on IBM, Univac, Burroughs, and CDC systems and three minicomputers, Digital Equipment Corporation, Hewlett-Packard, and Harris. Both HSPF and PRMS require disk storage. HYSIM can run with a tape or disk.

Considering the cumulative assessment needs, which are quantity and quality of water during high-and low-flow periods under seasonal conditions, and considering the capabilities of the available models and their current use and support, the HSPF system as supported by the USGS and EPA has the greatest 
capability to meet the needs of the major impact analysis. Discussion of HSPF implementation is found in a subsequent section of this report.

Input

Two types of data are required for routing models: (1) time-series and (2) physical descriptors. Time-series data include flow, suspended sediment, and other physical-chemical data for the permit area. At least daily values during low-flow periods and shorter time periods ( 5 minutes to 2 hours) during stormflow are necessary to use the routing method effectively. "Too complex" or "impossible" is usually the first reaction to the time-series requirement, and it definitely is when not approached properly. Long, continuous timeseries need not be much more difficult than short critical-event period simulations and in a few cases can be even easier. If the rainfall data are available on a data tape, the computer just has to compute more, but the user has little additional effort. When computer costs were much higher, this was a concern. With computer hardware costs dropping by a factor of 10 every decade, this has become a minor concern.

All routing models, critical event or continuous, require about the same set of parameters and physical dimensions to describe the drainage area. Needed parameters are: channel lengths, slope, shape, and roughness; soil characteristics; vegetal cover; fraction of impervious surfaces; pollutant accumulation and washoff rates; and physical-chemical-biological reaction parameters. All these parameters represent the second group of inputs, the physical descriptors.

Output

When continuous time-series are computed for points in a drainage basin, then any type of statistic can be computed such as the 10-year flood, flowduration curves, mean annual 3-day low flow, and combinations of conditions such as temperature, $\mathrm{pH}$, water depth, and dissolved oxygen that may be critical to a sport fishery. Software is available in HSPF to compute most of these statistics. HSPF software also can provide many types of tables and plots. No other method can provide the depth and flexibility of information as the continuous routing models.

Implementation

Routing models can provide the data to make a cumulative impact assessment but four steps are required to make them operational.

- Selection of a computer system.

- Model calibration and verification for major river basins in the coal provinces.

- Creating the data base and writing user manuals for each major river basin.

- Assigning staff or a consultant and training. 
Computer Requirements

Although any number of commercial or government computer systems could be used and computer time is widely available, the following must be considered:

(1) Method of access.

(2) Size of machine.

(3) Disk storage capacity.

(4) Cost algorithms.

Each user's needs and conditions are so different that generalizations are almost useless. Thus, the potential user is encouraged to discuss the computer requirements with experienced HSPF users. There is no cost for the HSPF software: Information and software are available from Tom Barnwell, Center for Water Quality Modeling, U.S. Environmental Protection Agency, College Station Road, Athens, Georgia 30613.

Three general comments can be made. The HSPF software is extremely well designed so that it can be overlayed and loaded on most mid-sized computers (minicomputers). Availability of disk storage is essential. A large number of input/output operations to the disk are made in an HSPF computer run which is important if those operations are included in the cost algorithm.

\section{Calibration/Verification}

After the computer system has been selected and HSPF loaded and checked with the test runs, the next step is acquiring the data and calibrating the model to the drainage basins of interest. This step requires expertise in watershed simulation which exists at the USGS and several consulting firms. Staff with graduate work in hydrology or several years experience with hydrologic modeling could be trained to do the calibration and verification. Although calibration and verification require experience, the operation of the model for impact assessment requires only a general understanding of hydrology and a few days of training. Attentive users of the model become quite aware of hydrologic processes as the operation of the model continues to train the user.

Tasks for calibration and verification include:

(1) Obtaining tapes of meteorologic data from the National Oceanic and Atmospheric Administration (NOAA), National Climatic Center, or the USGS.

(2) Obtaining tapes of streamflow and quality of water from the USGS.

(3) Obtaining the physical characteristics of the drainage basins from maps or geographic data bases.

(4) Processing the data to the appropriate HSPF files.

(5) Calibration of HSPF which involves adjusting certain parameters until the simulated time-series are similar to the measured time-series. 
(6) Verification of HSPF which involves applying HSPF to other time periods or gage location not previously used for calibration. This gives an estimate of the errors that can be anticipated.

Data Base and Users Manual

Once the model is calibrated and verified, data bases must be developed for the hydrometeorologic inputs and the physical characteristics of the drainage area. Most of these data are available from the calibration task and just need reorganization for the operation phase that evaluates the cumulative impacts. During the operation phase, model use becomes much simpler and an interactive program is utilized that asks questions and takes commands from the user. At this point, all the processing is done automatically and the results can be received on a line printer or a graphics display terminal, depending on the computer access methods selected. Graphics display terminal capabilities are not yet available with HSPF but are being developed. The details of the HSPF data base for each drainage basin impacted by coal mining would be combined with operation instructions to produce a users manual. Drainage basins could be any size, although on very large basins it becomes more difficult and costly. One application of HSPF is for 63,000 square miles of the Susquehanna River. Impacts of mining, however, are more apt to be confined to smaller basins up to a few hundred square miles.

\section{Staff and Training}

With the data base and user manual available, staff could be trained to operate the system for assessment of cumulative impacts. Although the initial costs to get to the operations phase may be relatively costly depending on the number and size of drainage basins, the operations cost should be no more than one staff person and the associated computer use. Economies would be gained if the calibrated model also was used by other agencies for analysis of other land-use changes and flow-regulation facilities.

\section{Impact Profile}

Following the computations of a minor or major impact analysis, the results could be presented as an impact profile as shown in Figure 4 . In the illustration $\mathrm{pH}$ changes due to acid mine drainage become a problem if no corrective measures are taken. Note at stream mile 98 the hypothetical stream classification and standards are changed to reflect a different use of the stream. Such profiles could be shown in several ways:

(1) Percent change in the physical-chemical characteristic versus stream mileage below the permit area.

(2) Physical-chemical characteristic before and after the permit and the stream standard versus stream mileage below the permit area.

In some cases, the material damage and permit decision may be based on a percentage change, while in other cases the decision may be based on the potential violation of a stream standard. 


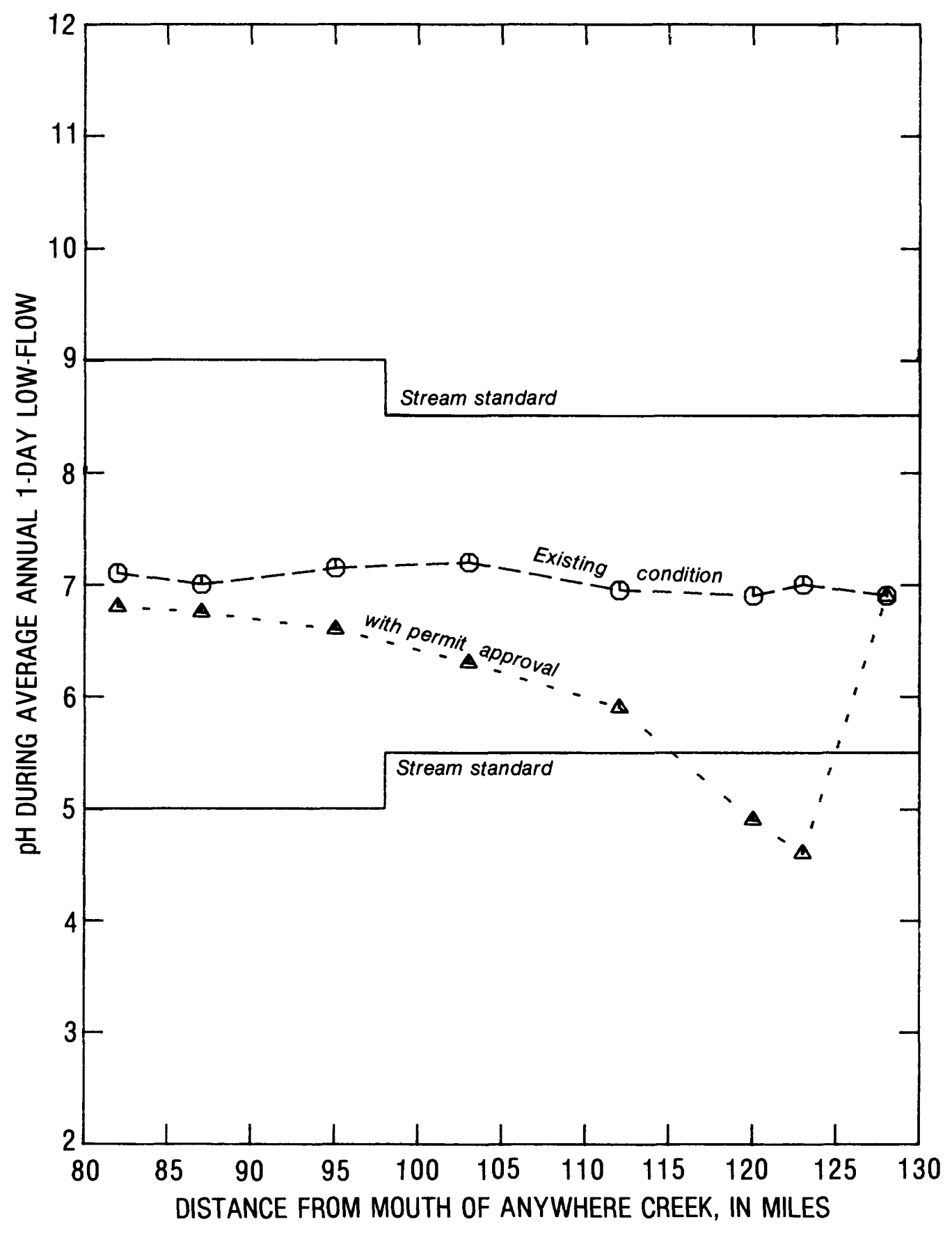

Figure 4.--Impact profile example. 


\section{ADEQUACY OF HYDROLOGIC EVALUATIONS FOR CUMULATIVE IMPACT ASSESSMENT}

Current information supplied by a hydrologic evaluation of a permit area is adequate for techniques used in a minor impact analysis, but not for routing techniques of a major impact analysis. Few coal mining operators are capable of producing the time-series estimates of flow, sediment, and physical-chemical properties from the permit area that are required by the major impact analysis. Because the operation of the routing model can be done easily and efficiently on a calibrated basin, one possible option is that (1) the coal mining operator only provide the details and maps describing the location and phases of the mining operation and all the physical dimensions, land-cover conditions, and soils characteristics of the permit area that are necessary for input to the model and (2) the regulatory authority do the computer simulations to produce the time-series. Then the simulated time-series of the quantity and quality of water from the permit area could be directly input to the analysis for the cumulative impact assessment. Efficiency could be gained and the evaluations, as well as the assessment, would be more accurate and consistent.

\section{CASE STUDY}

Data from the Tug Fork drainage basin are used to illustrate the procedures described in the previous sections. The Tug Fork drains 1,560 square miles of the Appalachian Plateaus in West Virginia, Kentucky, and Virginia. The valleys are narrow and the slopes are steep. Over 90 percent of the area is covered by deciduous forest. The mean annual rainfall of 44 inches is distributed throughout the year. Mean annual streamflow from the basin is equivalent to 16 inches. Thus, transpiration and evaporation is about 28 inches. Recharge to deep aquifers is negligible. The location of the basin is shown in Figure 5 .

No conclusion on the current status of the Tug Fork can be made from the following analysis because the location and extent of mining were selected to demonstrate the techniques and do not reflect the actual conditions in the watershed. Only flow characteristics are used in the analysis, but the physical-chemical-biological characteristics of the water also could be assessed with the same techniques.

\section{Hydrologic Activity Profile}

The activity profile shown previously in Figure 3 is based on the assumption that 3,000 acres are being surfaced mined in Jacob Fork near Newha11, W. Va. Jacob Fork is tributary to Dry Fork which is tributary to Tug Fork. Piver miles for downstream reaches were taken from the Special Flood Hazard Information Report, Tug Fork of Sandy River (U.S. Army Corps of Engineers, 1978) and river miles for tributary reaches were taken from topographic maps. Drainage boundaries were drawn and areas were measured on the topographic maps. 


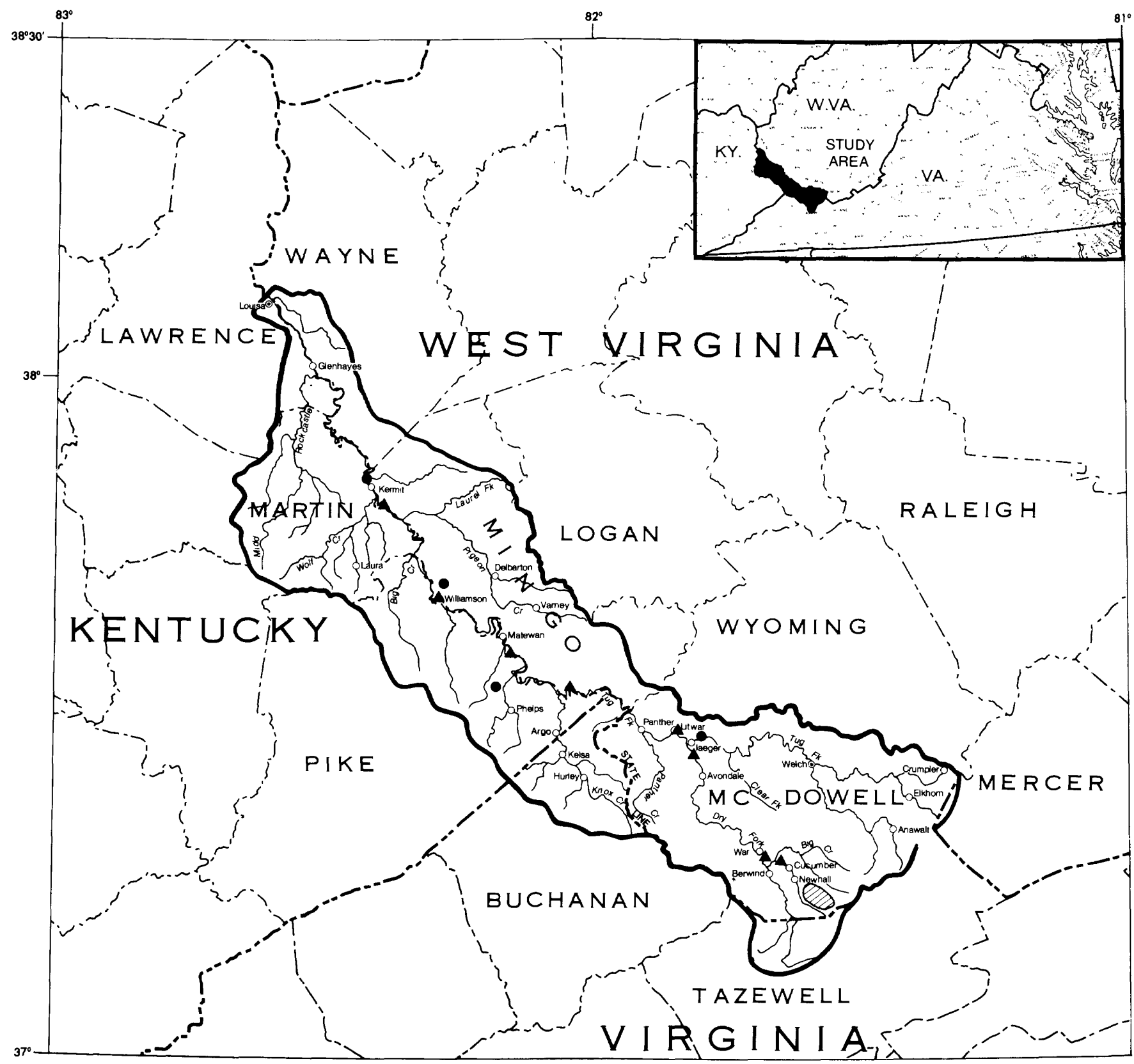

EXPLANATION

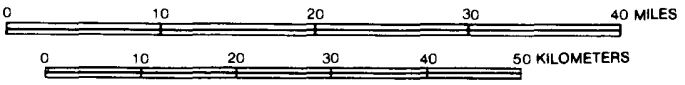

- Raingage Used in Routing Model

$\bigotimes$ Assumed Surface Mining

- Routing Model Output

Figure 5.--Location of the Tug Fork basin. 
Many features could be placed on the activity profile to assist in deciding whether a minor impact analysis or major impact analysis may be necessary. Such features might include:

(1) Location of reservoirs.

(2) Communities, cities, and towns.

(3) Water-supply intakes.

(4) Waste-water discharges.

(5) State stream classification.

(6) Recreation areas.

(a) Fishing.

(b) Camping/picnicing/swimming.

(c) Flatwater boating.

(d) Whitewater boating.

Most of the information on the Tug Fork is taken from the USGS report, Hydrology of Area 13, Eastern Coal Province, and the 1981 U.S. Army Corps of Engineers report "Tug Fork Valley, Flood Damage Reduction Plan." Along the Tug Fork exists many small communities; the larger communities are indicated on the profile. Only two communities have waste-water treatment plants. Four communities take their water supply from the main stem of the Tug Fork even though bacterial levels are one to two orders of magnitude above standards in many sections of the main stem. Turbidity, iron, and maganese levels are high. Thus, little recreation takes place on the main stem of the Tug Fork. However, West Virginia regulations have deemed the entire Tug Fork usable for water-contact recreation, water supply, propagation of fish and other aquatic life, and treated wastes transport and assimilation.

\section{Impact Matrix}

An impact matrix resulting from hypothetical surface mining in Jacob Fork is shown on Table 3. No impact is indicated for surface-water reservoirs because there are none. Temperature, listed under aquatic life, also is checked as no impact but would be checked as a major impact if some of the surface-mining activities were located on the tributary streams designated as trout fisheries. No navigation or hydroelectric power exists in the Tug Fork. Acidity and pH were checked as no impact since the coal in the Tug Fork has low sulfur content and no acid-mine drainage problems exist. Flooding, sediment, and heavy metals are the major impacts on the Tug Fork.

\section{Minor Impact}

Flow data are used to illustrate the numeric techniques. From the assumed hydrologic evaluation of the 3,000 acres of permit area on Jacob Fork, the needed information is abstracted and presented in Table 4. For later comparison, the values were taken from the computer simulation of the hypothetical permit area which is discussed in the next section of this report. Normally the values in Table 4 would be abstracted from the USGS Coal Hydrology Reports and the hydrologic evaluation of the permit area. 
Table 3.--Impact matrix - Tug Fork, W. Va.

\begin{tabular}{|c|c|c|c|c|c|}
\hline \multirow[b]{2}{*}{$\begin{array}{l}\text { Material } \\
\text { Damage }\end{array}$} & \multirow[b]{2}{*}{$\begin{array}{c}\text { Physical-Chemical } \\
\text { Characteristics }\end{array}$} & \multirow[b]{2}{*}{$\begin{array}{l}\text { Stream Standards } \\
\text { or Other Criteria* }\end{array}$} & \multicolumn{3}{|c|}{$\begin{array}{c}\text { Checklist for } \\
\text { Impacts Based on Degree of } \\
\text { Impact** }\end{array}$} \\
\hline & & & $\begin{array}{c}\text { no } \\
\text { impact }\end{array}$ & $\begin{array}{r}\text { minor } \\
\text { impact }\end{array}$ & $\begin{array}{r}\text { major } \\
\text { impact }\end{array}$ \\
\hline \multirow{6}{*}{$\begin{array}{l}\text { WATER SUPPLY } \\
\text { Surface Water } \\
\text { Streams }\end{array}$} & Low flow & & & $レ$ & \\
\hline & Stage & & & $r$ & \\
\hline & Alkalinity, acidity, $\mathrm{pH}$ & & $r$ & & \\
\hline & Suspended solids & & & & $r$ \\
\hline & Heavy metals & & & & 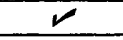 \\
\hline & Salts & & & $\checkmark$ & \\
\hline \multirow{6}{*}{$\begin{array}{l}\text { Surface Water } \\
\text { Reservoirs }\end{array}$} & Flow (yield) & & 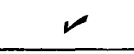 & & \\
\hline & Stage & & $\checkmark$ & & \\
\hline & Alkalinity, acidity, $\mathrm{pH}$ & & 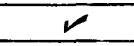 & & \\
\hline & Suspended solids & & $\bar{v}$ & & \\
\hline & Heavy metals & & 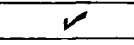 & & \\
\hline & Plankton & & 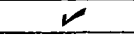 & & \\
\hline \multirow[t]{3}{*}{ Ground water } & Water level & & 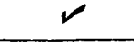 & & \\
\hline & Porosity (storage) & & 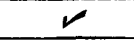 & & \\
\hline & Leachate & & & 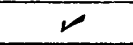 & \\
\hline \multirow{5}{*}{ FLOOD PRONE } & Flood frequency & & & & $\checkmark$ \\
\hline & Stage & & & & 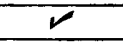 \\
\hline & Suspended solids & & & & $r$ \\
\hline & Velocity & & & & $r$ \\
\hline & Channel configuration & & & & $r$ \\
\hline \multirow{5}{*}{$\begin{array}{l}\text { WATER-CONTACT } \\
\text { RECREATION } \\
\text { Boating, } \\
\text { swimming, } \\
\text { fishing }\end{array}$} & Depth and stage & & $\checkmark$ & & \\
\hline & Velocity & & $\checkmark$ & & 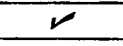 \\
\hline & Suspended sediment & & & & 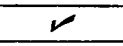 \\
\hline & Heavy metals & & & & \\
\hline & Alkalinity, acidity, $\mathrm{pH}$ & & $\nu$ & & \\
\hline \multirow{12}{*}{$\begin{array}{l}\text { AQUATIC LIFE } \\
\text { plankton, } \\
\text { benthos, } \\
\text { fish, } \\
\text { Aquatic and } \\
\text { riparian } \\
\text { vegetation }\end{array}$} & Depth and Stage & & $\sim$ & & \\
\hline & Water surface area & & 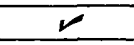 & & \\
\hline & Channel configuration & & 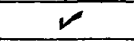 & & \\
\hline & Velocity & & $\checkmark$ & & \\
\hline & Temperature & & 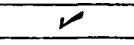 & & $\bar{V}$ \\
\hline & Alkalinity, acidity, $\mathrm{pH}$ & & & r & \\
\hline & Light transmissivity & & & & $r$ \\
\hline & Heavy metals & & & 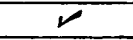 & \\
\hline & Suspended solids & & $r$ & & \\
\hline & Bed material & & & $r$ & \\
\hline & Salts & & & V & \\
\hline & Flood frequency & & & 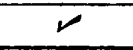 & \\
\hline \multirow[t]{3}{*}{ NAVIGATION } & Velocity and depth & & v & & \\
\hline & Suspended solids & & $v$ & & \\
\hline & Acidity, pH & & $r$ & & \\
\hline \multirow{3}{*}{$\begin{array}{l}\text { HYDROELECTRIC } \\
\text { POWER }\end{array}$} & Flow & & $v$ & & \\
\hline & Suspended solids & & 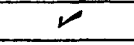 & & \\
\hline & Acidity, pH & & $r$ & & \\
\hline
\end{tabular}

*To be established by Regulatory Authority

**Based on hydrologic activity profile 
Table 4.--Flow characteristics for the permit area.

Before mining (25-year simulation period)

Maximum Daily Discharge

$=891 \mathrm{ft}^{3} / \mathrm{sec}$

Minimum Daily Discharge

$=0.08 \mathrm{ft}^{3} / \mathrm{sec}$

Mean of the Annual Maximum Daily

Discharges

$=193.6 \mathrm{ft}^{3} / \mathrm{sec}$

Mean Daily Flow (May-0ct)

$=2.99 \mathrm{ft}^{3} / \mathrm{sec}$

Mean Daily Flow (Nov-Apr)

$=8.07 \mathrm{ft}^{3} / \mathrm{sec}$

Percent Time 7-Day Flow Less

$1 \mathrm{cfs}($ May-0ct) $=31.9 \%$

After mining (25-year simulation period)

Maximum Daily Discharge

$=1,057 \mathrm{ft}^{3} / \mathrm{sec}$

Minimum Daily Discharge

$=0.55 \mathrm{ft}^{3} / \mathrm{sec}$

Mean of the Annual Maximum Daily

Discharges

$=229.2 \mathrm{ft}^{3} / \mathrm{sec}$

Mean Daily Flow (May-0ct)

$=6.82 \mathrm{ft}^{3} / \mathrm{sec}$

Mean Daily Flow (Nov-Apr)

$=9.37 \mathrm{ft}^{3} / \mathrm{sec}$

Percent Time 7-Day Flow Less

1 cfs (May-0ct)

$=1.2 \%$

Change in flow characteristics

$\begin{array}{lll}\text { Maximum Daily Discharge } & =+166 \mathrm{ft}^{3} / \mathrm{sec} \\ \text { Minimum Daily Discharge } & =+0.47 \mathrm{ft} 3 / \mathrm{sec} \\ \text { Mean of the Annual Maximum Daily } & =+35.6 \mathrm{ft}^{3} / \mathrm{sec} \\ \quad \text { Discharges } & =+3.83 \mathrm{ft}^{3} / \mathrm{sec} \\ \text { Mean Daily Flow (May-Oct) } & =+1.3 \mathrm{ft}^{3} / \mathrm{sec} \\ \text { Mean Daily Flow (Nov-Apr) } & =\end{array}$


Using (1) the data in Table 4, (2) equations 1, 3, and 5, and (3) drainage areas of Dry Fork at War and the mine site to be 114 square miles and 5 square miles, respectively, a minor impact analysis was made. Results are shown in Table 5. The same analysis also should be conducted to check other points downstream.

$$
\begin{gathered}
\text { Table 5.--Results of minor impact analysis. } \\
\text { Dry Fork at War, W. Va. }
\end{gathered}
$$

\begin{tabular}{|c|c|c|c|c|}
\hline \multirow{2}{*}{$\begin{array}{l}\text { Physical } \\
\text { Characteristic }\end{array}$} & \multicolumn{4}{|c|}{ Discharge $\left(\mathrm{ft}^{3} / \mathrm{sec}\right)$} \\
\hline & Before ${ }^{1}$ & Change $^{2}$ & After ${ }^{3}$ & Increase 4 \\
\hline $\begin{array}{l}\text { Maximum Daily } \\
\text { Discharge }\end{array}$ & 18800 & 166 & 18866 & $0.9 \%$ \\
\hline $\begin{array}{l}\text { Minimum Daily } \\
\text { Discharge }\end{array}$ & 1.86 & 0.47 & 2.33 & $25.3 \%$ \\
\hline $\begin{array}{l}\text { Mean of the Anne } \\
\text { Maximum Daily } \\
\text { Discharge }\end{array}$ & 4054 & 35.6 & 4089.6 & $0.8 \%$ \\
\hline $\begin{array}{l}\text { Mean Daily Flow } \\
(\text { May-Oct) }\end{array}$ & 68.31 & 3.83 & 72.14 & $5.6 \%$ \\
\hline $\begin{array}{l}\text { Mean Daily Flow } \\
\text { (Nov-Apr) }\end{array}$ & 184.4 & 1.30 & 185.7 & $0.7 \%$ \\
\hline
\end{tabular}

lFrom hydrology of general area, in this case computer simulation, $Q_{C}$.

${ }^{2}$ From hydrologic evaluation of permit area, in this case computer simulation, Dif or Dff.

${ }^{3}$ Equation 3 or $5, Q_{n c}$.

${ }^{4}$ Equation 2 or 4 , $P$.

Depending on the stream standard or criteria, the permits could be approved or denied. In this case, the major change is an increase in low flow which would be a desirable impact since the river is used mostly for water supply and waste-water assimilation. Increases in floodflows are minor yet might be reduced by requirements of detention storage at the site. In the Tug Fork basin, sediment is likely to be the major problem, which would require detention storage and other erosion control measures. 
Major Impact

The routing model, HSPF, was used for the major impact analysis. Each of the four steps are used for this case study.

(1) The routing model was loaded and tested on the computer at the USGS.

(2) Model calibration and verification were accomplished by obtaining data tapes of streamflow from the WATSTORE system of the USGS, Reston, Va., and State tapes of meteorological data, TD-9655, and TD-9654, for the States of West Virginia and Kentucky from the National Climatic Center, NOAA, Asheville, N.C. Four daily rain gages at Kermit, Williamson, Freeburn, and Iaeger were selected and used. Pan evaporation data from Bluestone Dan were selected. If the analysis had not been just for the purpose of illustration of the technique, hourly rainfall data would have been used from about seven nearby stations. Next, rainfall for periods of missing record was estimated from the other gages so each of the four records were complete. A 25-year rainfall record, 1954-1978, was used. The model was calibrated using the 1974-1978 period. Since the routing model, HSPF, previously had been calibrated on similar watersheds, the initial approximation and final selection of rainfall-runoff parameters were very close. Only one parameter, the infiltration rate, was changed to get a better match of simulated and measured streamflow. Further adjustments would refine the calibration but were not necessary for this illustration. Other input to the model included (1) lengths of channel reaches and drainage areas which were taken from maps or Corps of Engineers reports and (2) rating tables for the reaches which were developed from stream-gaging data on the Tug Fork available from the USGS. Although daily rainfall data were input, a simulation timestep of 6 hours was selected because the traveltime through each of the eight reaches was approximately 6 hours. Simulated 6 -hour flows from each reach were summed for each day and written to a daily file for later statistical analysis, printing, and plotting. Selected results of the verification are shown on Figures 6,7 , and 8. Day-to-day matches of computed and observed flows were not as good as could be since only four rain gages were used (Figure 6 ). Although rainfall is distributed throughout the year, streamflow is very low during the summer. The routing model reproduced this effect but was off on the timing as shown in Figure 7. Over the 1954 to 1978 period, the annual flow from simulation was low by 11 percent as shown in Figure 8. Adding more soil moisture storage capacity and reducing the potential evapotranspiration parameters in the winter would correct the above discrepancies. No pan evaporation data were available during the winter months, so the values were estimated.

(3) A users manual should be developed for the verified routing model so others could easily use the system. In this case study, 25 years of rainfall and pan evaporation data were created for the Tug Fork as input time-series data to the model for quantifying the impacts. Figure 5 shows the segments and rain gages used for the model applications. 


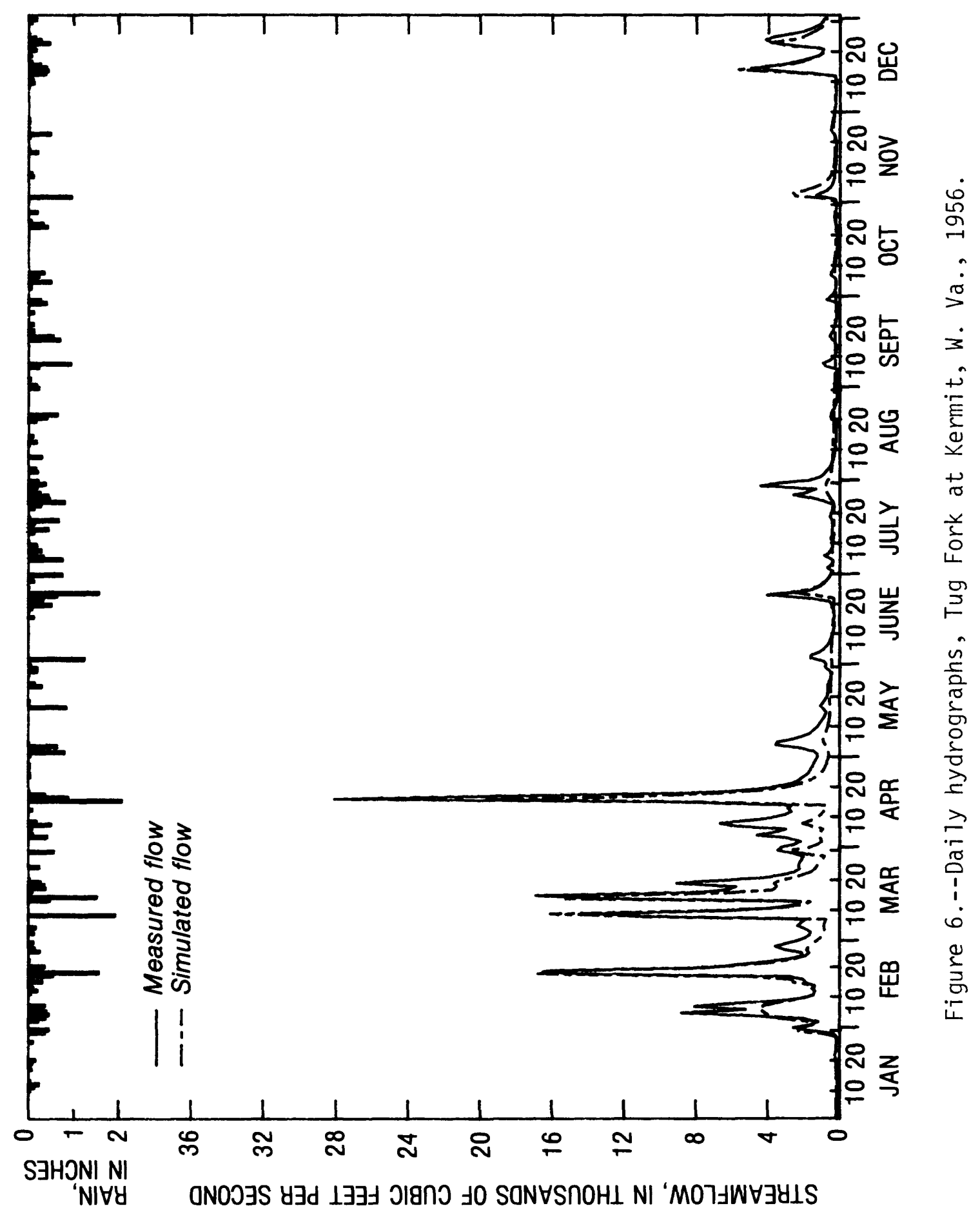




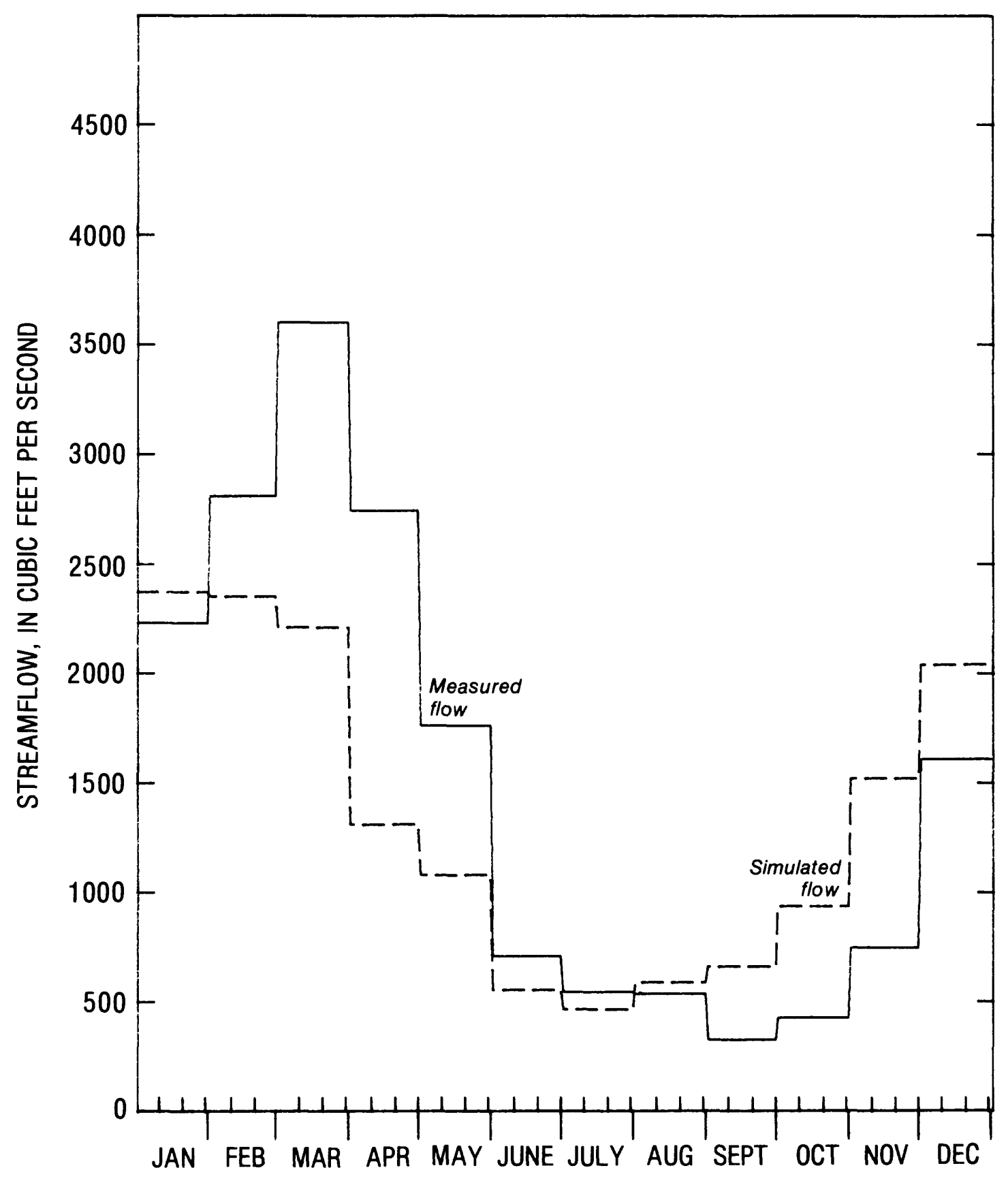

Figure 7.--Mean monthly flow, Tug Fork at Kermit, W. Va., 1980. 


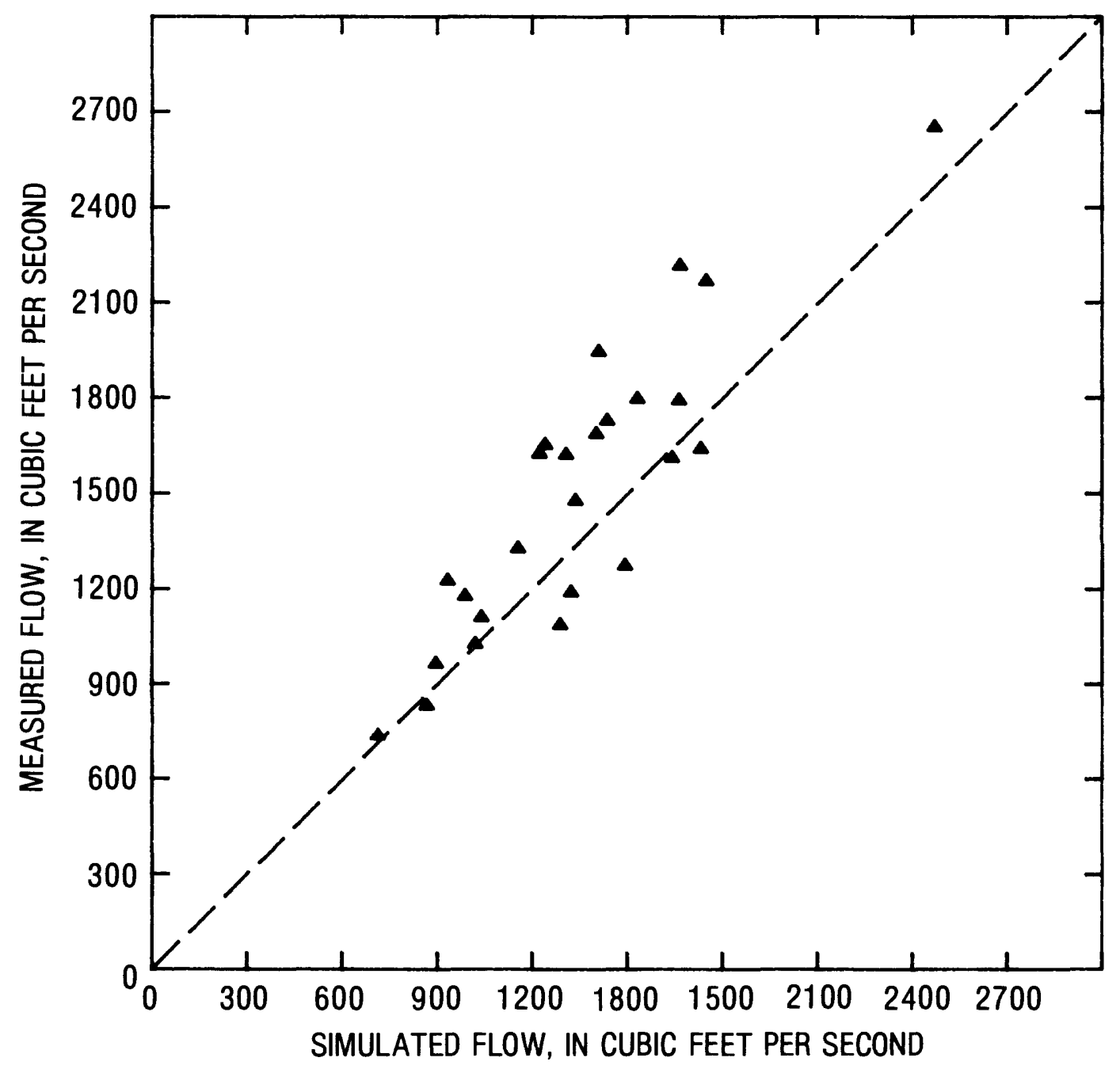

Figure 8.--Annual flows, Tug Fork at Kermit, W. Va. 
For an illustration of the application of the model, 3,000 acres were assumed to be surface mined in Jacob Fork near Cucumber, W. Va. Parameters in the model must be changed to reflect the new conditions. Six parameters are commonly used: (1) infiltration; (2) interception by vegetation; (3) soil storage capacity; (4) land surface storage capacity; (5) overland flow slope, length, and roughness; and (6) vegetal index to transpiration. For this illustration, only two were changed: (a) interception by vegetation, and (b) vegetal index to transpiration. This assumes that the deciduous forest cover was removed, but none of the soil characteristics were changed. Although such an assumption does not include the full impact of surface mining, it illustrates the importance of vegetation and revegetation and the cumulative effects of vegetation on soil moisture. Detention storage ponds were not included. Guidelines are available with HSPF for adjustment of the parameters for the effect of vegetation and these were used to determine the amount the parameter should be changed (Johanson, 1980). Other guidelines are being developed as the model is used on intensely gaged streams in agricultural, urban, and surface-mining environments.

Flow was simulated for 25 years with and without the change in the two parameters. Tables $6,7,8$, and 9 trace the impact of the 3,000 acres of surface mining on downstream flows. Figures 9 and 10 show the changes in daily flow duration from the 3,000-acre site for the 1954-1978 simulation period. The percent change drops rapidly as the accumulated drainage area exceeds 20 times the area being mined. A large difference exists between the summer and winter impacts. Many other types of statistics could be used since continuous time-series of daily flows exist on computer files for the before and after mining conditions. Only a few of the possibilities are illustrated in the tables.

Impact Profile

Data on Table 7 are displayed graphically on Figure 11 as an impact profile. In this case, streamflows are drawn. For purposes of assessing impacts on flood levels, the water-surface elevations before and during surface mining could be plotted along with the elevation that flood damages begin to occur.

Comparison of Major and Minor Impact Analysis

For some characteristics the computed change is the same using techniques of the minor and major impact analysis. Mean daily flow and minimum daily flow are examples. Floodflows are not because floods attenuate as they move downstream. Table 10 and the impact profile in Figure 12 were developed to illustrate the difference and show the percent increase in floodflows downstream using both techniques. The more realistic values are from the routing model. Note that the peak flows decrease from Matewan to Williamson even though the Tug Fork at Williamson drains a larger area. This phenomenon, which also is found in the measured data, occurs since the effects of the attenuation of the floodwave from Matewan to Williamson are greater than the effects of additional water from tributaries. In this case the added tributary area is relatively small. 


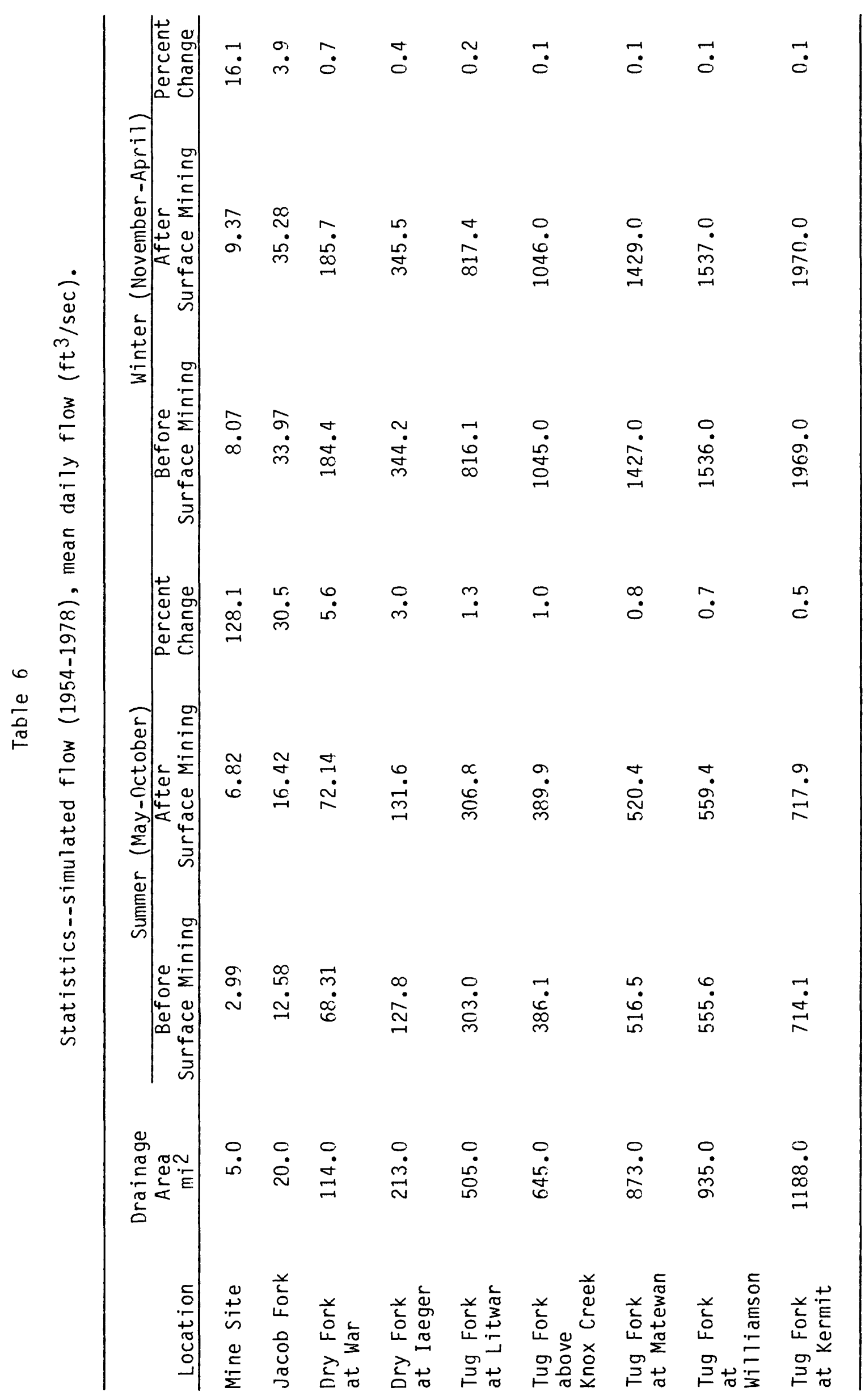




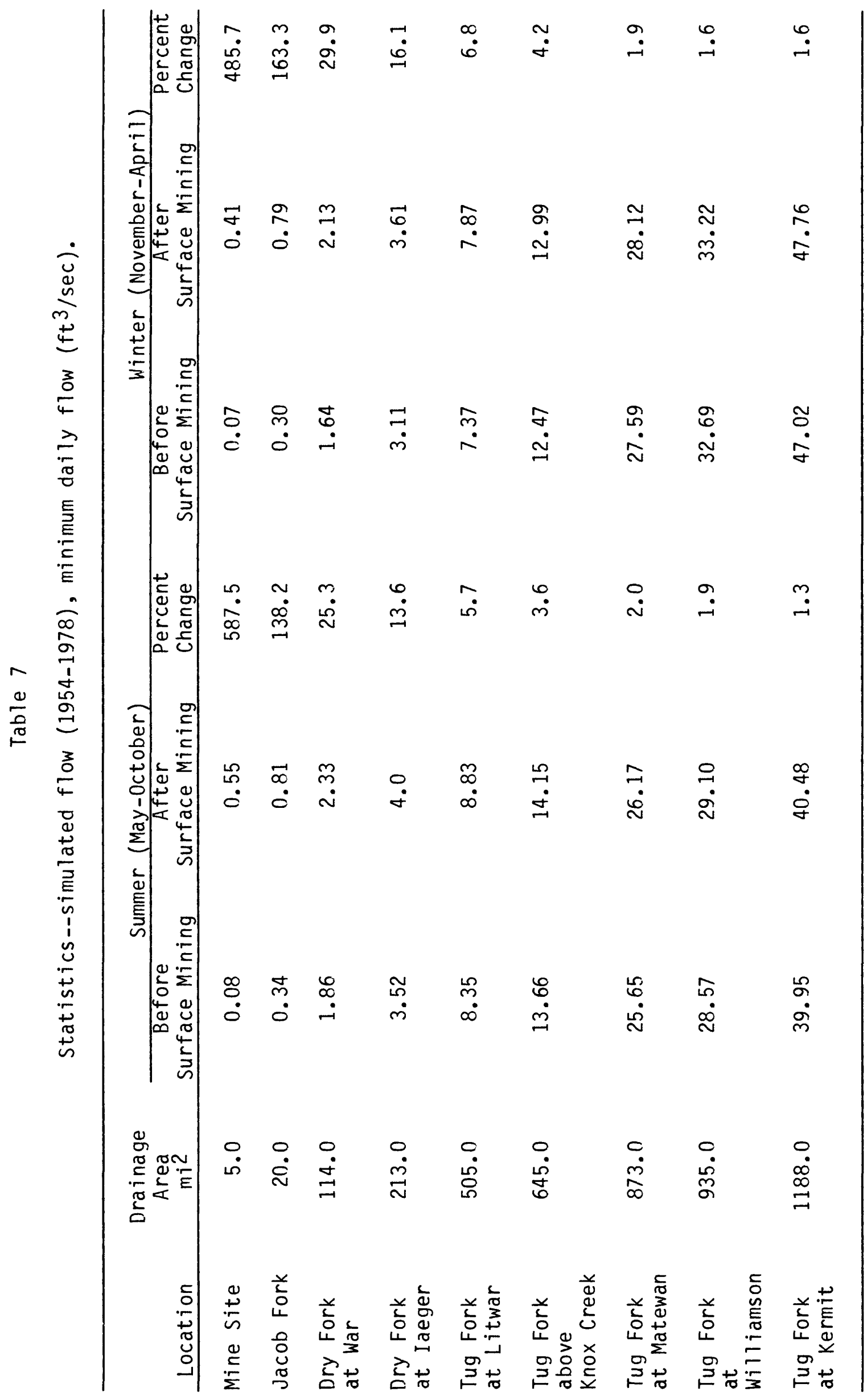




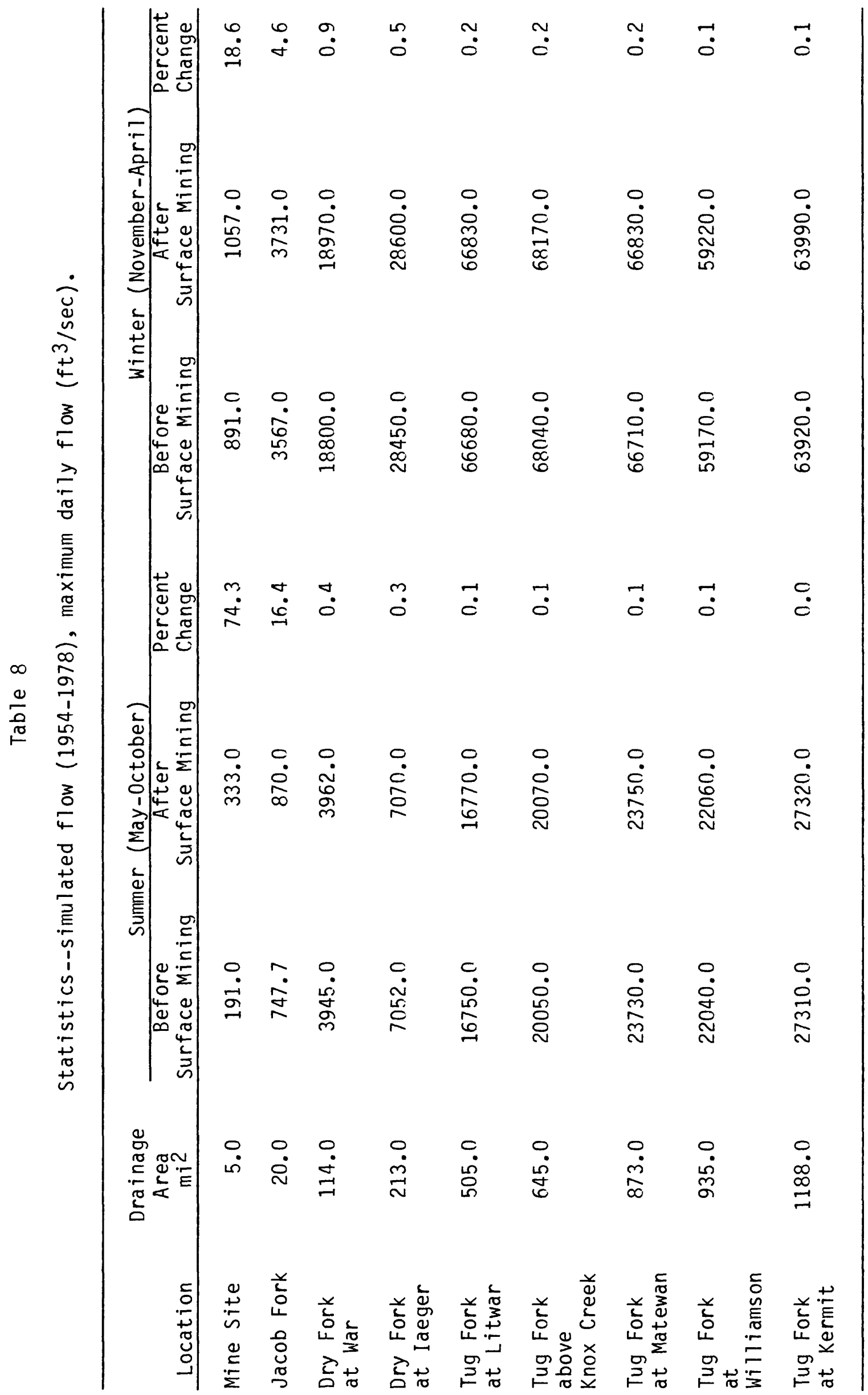


Table 9

Statistics--simulated flow (1954-1978), mean of the annual maximum daily flow $\left(\mathrm{ft}^{3} / \mathrm{sec}\right)$.

\begin{tabular}{|c|c|c|c|c|}
\hline $\begin{array}{l}\text { Critical } \\
\text { Point }\end{array}$ & $\begin{array}{c}\text { Drainage } \\
\text { Area } \\
\mathrm{mi}^{2}\end{array}$ & $\begin{array}{c}\text { Before } \\
\text { Surface Mining }\end{array}$ & $\begin{array}{c}\text { After } \\
\text { Surface Mining }\end{array}$ & $\begin{array}{l}\text { Percent } \\
\text { Change }\end{array}$ \\
\hline Mine Site & 5.0 & 193.6 & 229.2 & 18.4 \\
\hline Jacob Fork & 20.0 & 771.0 & 796.0 & 3.2 \\
\hline $\begin{array}{l}\text { Dry Fork } \\
\text { at War }\end{array}$ & 114.0 & 4054.0 & 4077.0 & 0.6 \\
\hline $\begin{array}{l}\text { Dry Fork } \\
\text { at Iaeger }\end{array}$ & 213.0 & 6302.0 & 6322.0 & 0.3 \\
\hline $\begin{array}{l}\text { Tug Fork } \\
\text { at Litwar }\end{array}$ & 505.0 & 15080.0 & 15100.0 & 0.1 \\
\hline $\begin{array}{l}\text { Tug Fork } \\
\text { above } \\
\text { Knox Creek }\end{array}$ & 645.0 & 17360.0 & 17380.0 & 0.1 \\
\hline $\begin{array}{l}\text { Tug Fork } \\
\text { at Matewan }\end{array}$ & 873.0 & 22160.0 & 22180.0 & 0.1 \\
\hline $\begin{array}{l}\text { Tug Fork at } \\
\text { Williamson }\end{array}$ & 935.0 & $21320 . ?$ & 21330.0 & 0.1 \\
\hline $\begin{array}{l}\text { Tug Fork } \\
\text { at Kermit }\end{array}$ & 1188.0 & 25290.0 & 25310.0 & 0.1 \\
\hline
\end{tabular}


Table 10.--Comparison of minor and major impact analysis techniques.

Maximum daily flow--summer period ( $\left.\mathrm{ft}^{3} / \mathrm{sec}\right)--1954-1978$

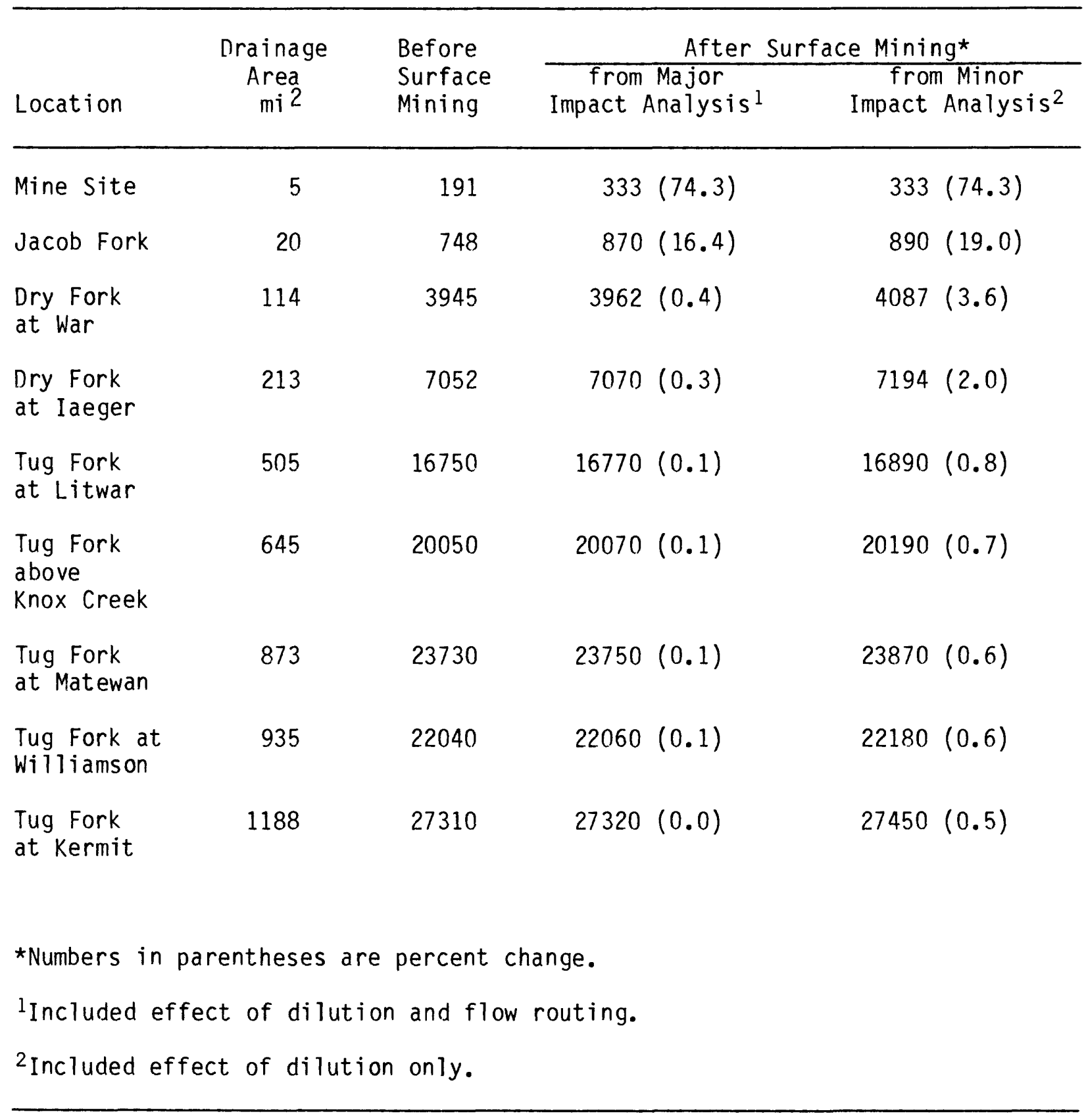




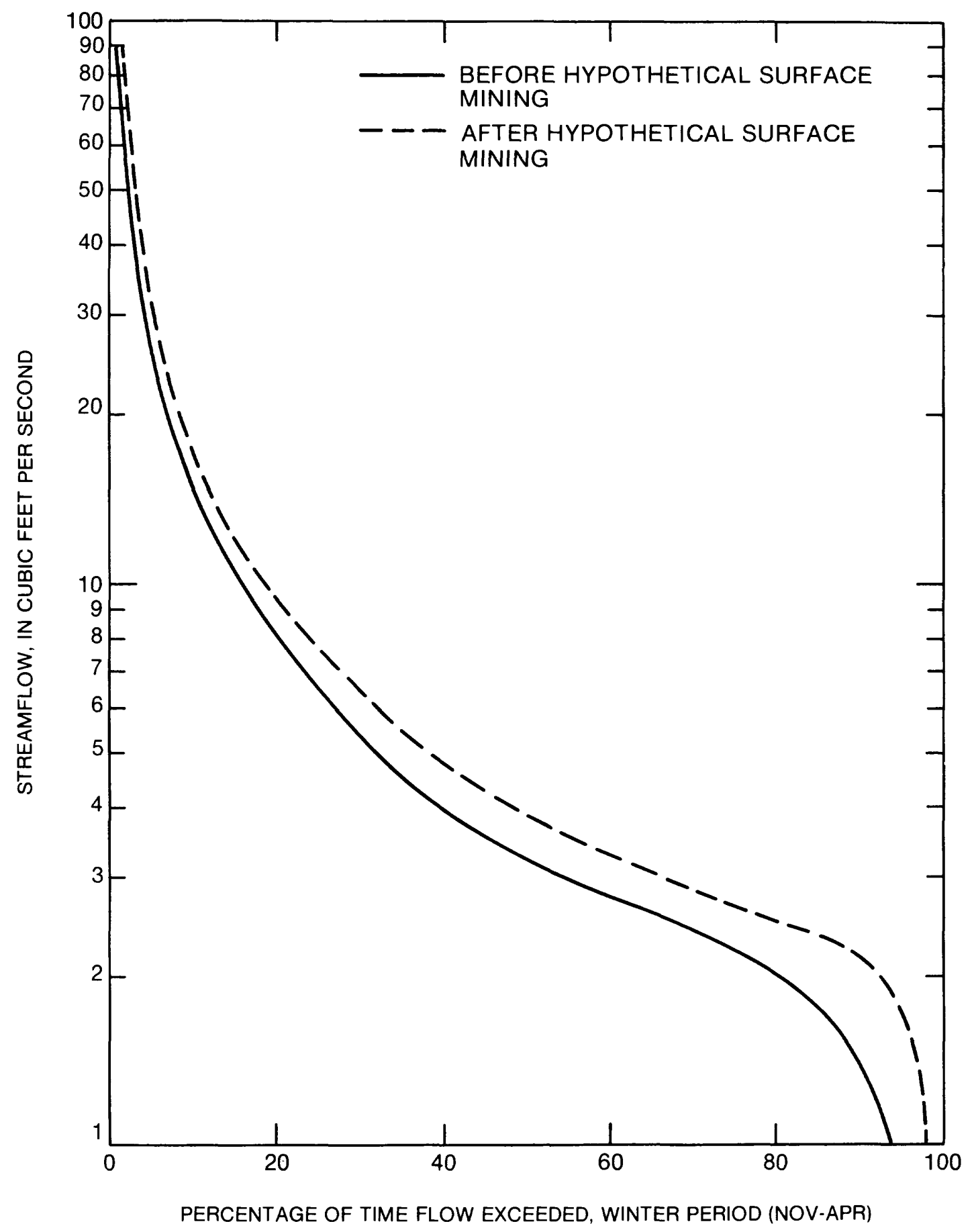

Figure 9.--Flow duration, simulated flow, Jacob Fork, winter period. 


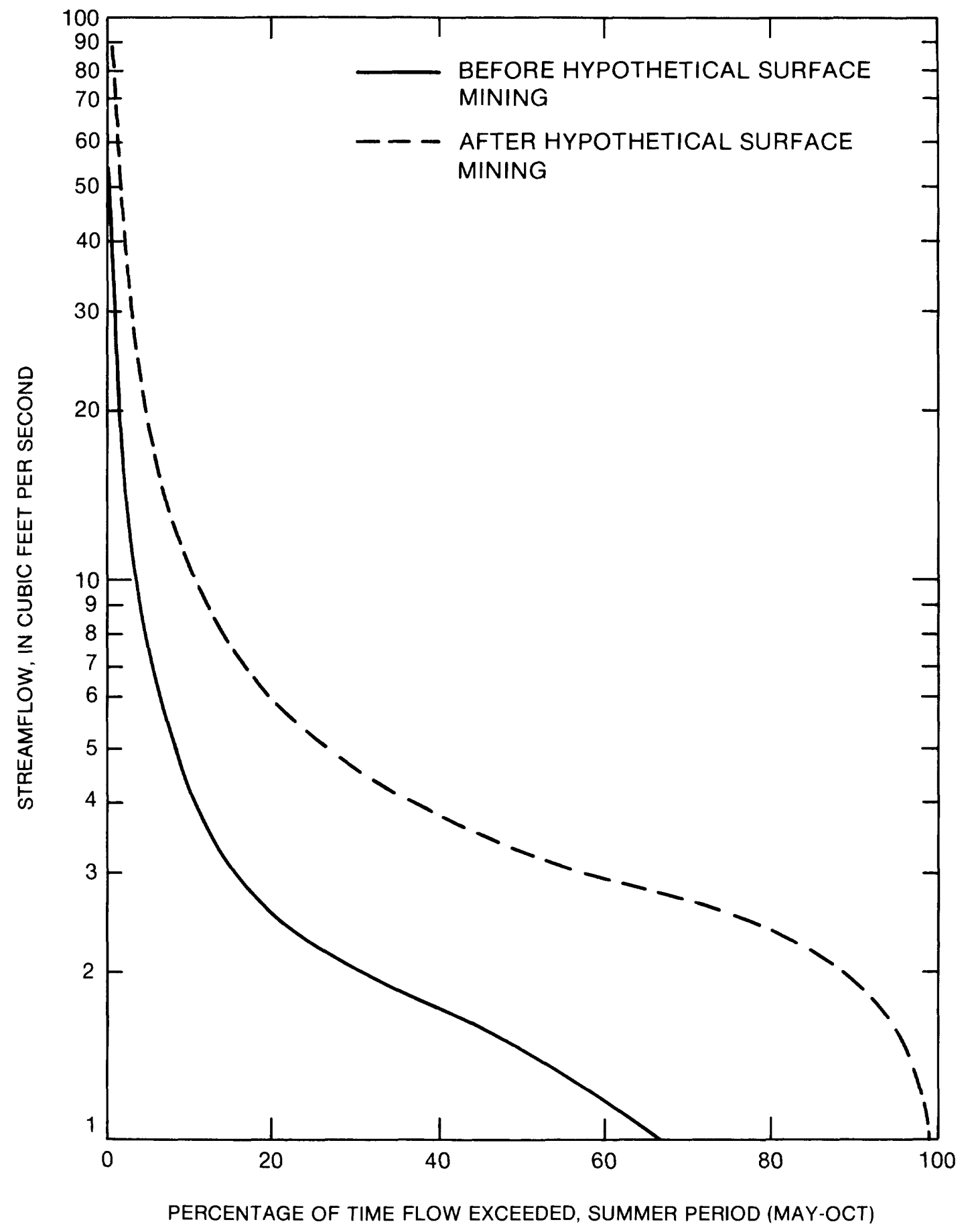

Figure 10.--Flow duration, simulated flow, Jacob Fork, summer period. 


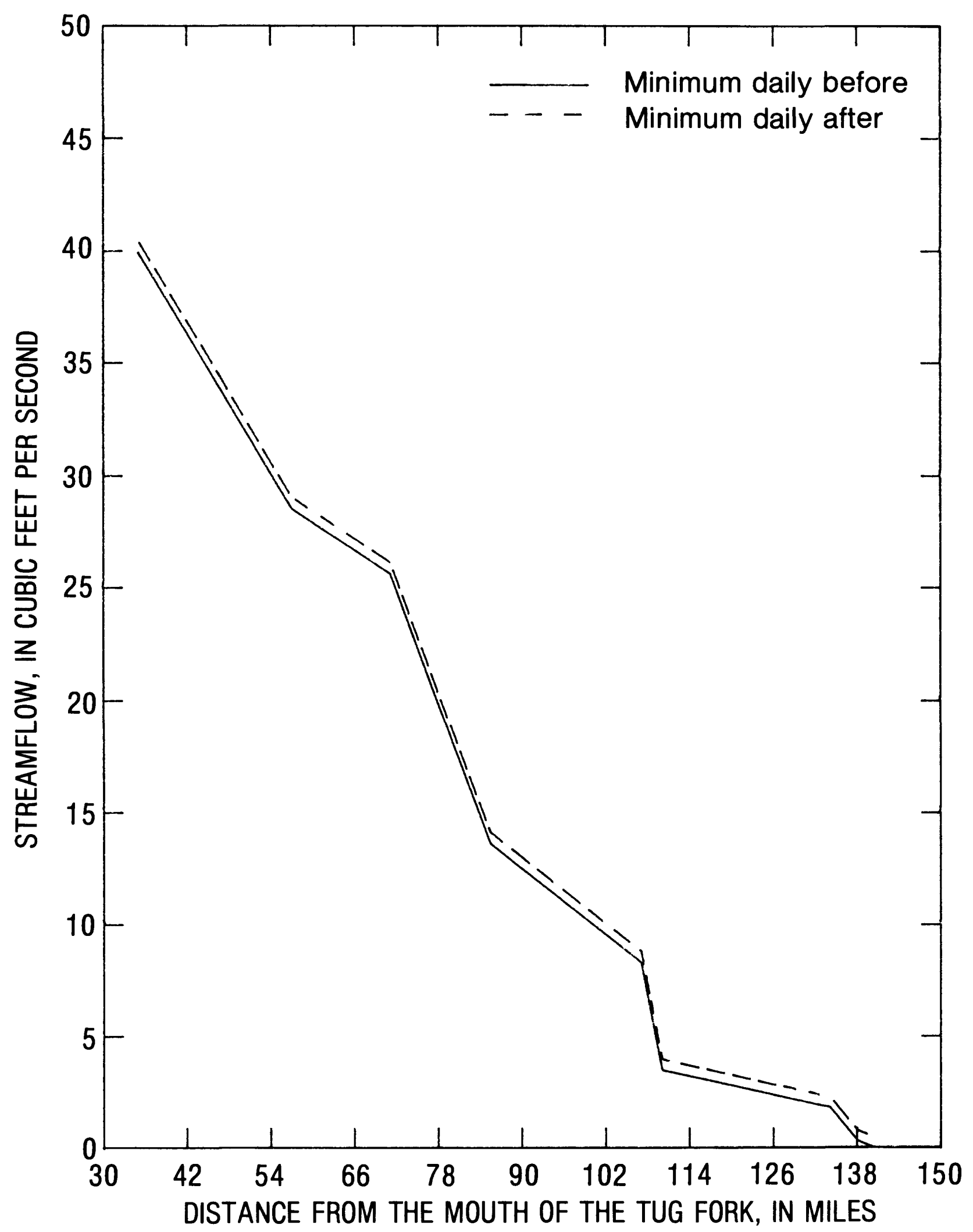

Figure 11.--Impact profile, minimum daily flow, summer period. 


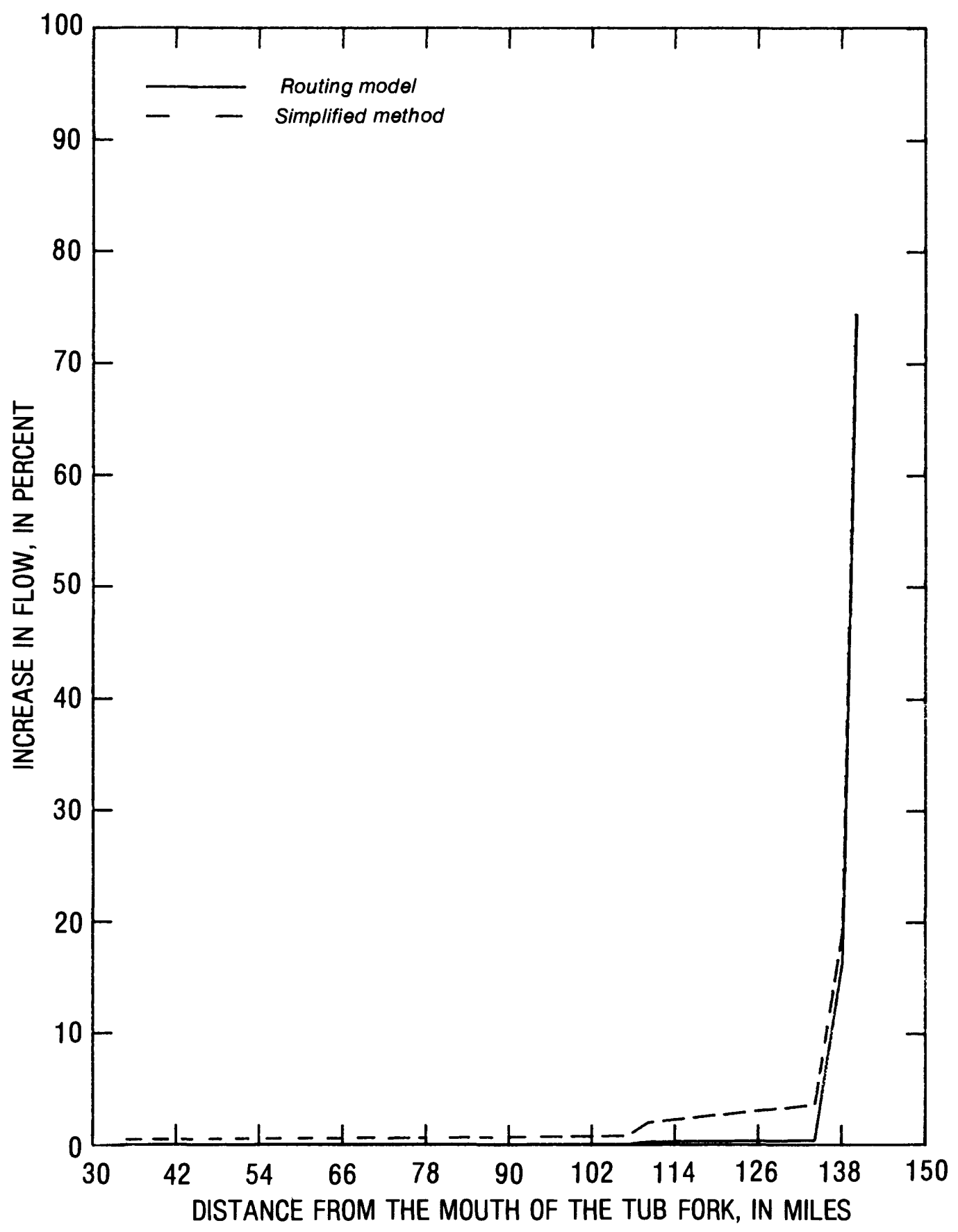

Figure 12.--Impact profile, maximum daily flow, summer period. 


\section{CONCLUSIONS}

A review of the Federal legislation on surface mining, a review of the available hydrologic techniques, and a case study using the proposed techniques has lead to the following conclusions.

(1) Standard hydrologic methods for storm hydrograph analysis do not meet the needs of a regulatory authority for making cumulative impact assessments.

(2) A simplified yet conservative approach can be used as a minor impact analysis to screen many cases where the impacts are judged to be of minor consequence.

(3) Simulation with a rainfall-runoff, water-quality and routing model for a period of a year or more can be used for a major impact analysis, meets the needs of the regulatory authority, is feasible, but may be too complex or costly.

\section{FUTURE WORK}

The case study described herein only illustrates the methods and techniques developed for cumulative impact assessments. Next, three pilot basins should be selected to thoroughly test these methods and techniques. Such tests would be able to utilize the computer software that is being developed for the USGS to make the comprehensive routing model much easier to apply. That software will be tested for general applications in the spring of 1982.

The pilot basins should include one basin each from the E'astern, Interior, and Western Coal Provinces. At least one basin should have acid drainage problems. All pilot basins should include some extensive hydrometeorological data collected by the USGS on watersheds with surfacé-mining activities.

A different work team should be assigned to each pilot basin to identify as many problems with the techniques as possible. Each work team should include the appropriate regulatory authority. All work teams should have a 1-week training session, and a preliminary users manual should be written for the training. As the problems are identified and resolved, the users manual and computer software should be updated as practical.

In addition to the manual application of the equations for the minor impact analysis, a computer program should be written to load the procedures on a desktop microcomputer. Both the manual and computer application of the minor impact analysis techniques should be tested.

Each pilot basin study should assess the cost effectiveness of the techniques and make recommendations for changes. If the techniques are cost effective, plans for implementation must be developed. 


\section{REFERENCES}

Bales, Jerad, 1979, TVA strip mine assessment model : Hydrologic component: in Symposium on Surface Mining Hydrology Sedimentology and Reclamation, University of Kentucky, Lexington, Ky., pp. 265-270.

Beasley, D. B., Monke, E. J., and Huggins, L. F., 1977, ANSWERS: A model for watershed planning: Purdue Agricultural Experiment Station, Journal Paper No. $7038,34 \mathrm{p}$.

Berkas, Wayne Richard, 1978, Deterministic watershed model for evaluating the effects of surface mining on hydrology: MS Thesis, University of Arizona.

Betson, Roger P., Bales, Jerad, and Pratt, Harold E., 1980, User's Guide to TVA-HYSIM: A hydrologic program for quant ifying land-use change effects: EPA-600/70-80-048, Industrial Environmental Research Laboratory, Cincinnati, Ohio, $81 \mathrm{p}$.

Boyer, James F., and Gleason, Virginia E., 1977, Coal and coal mine drainage: Journal Water Pollution Control Federation, pp. 1163-1172.

Brandt, G. H., et a1., 1972, An economic analysis of erosion and sediment control methods for watersheds undergoing urbanization, Final report: Dow Chemical Company, Midland, Mich.

Brown, J. W., et a1., 1974, Models and methods applicable to Corps of Engineers urban studies: U.S. Army Engineer Waterways Experiment Station, Vicksburg, Miss., 382 p.

Brune, G. M., 1953, Trap efficiency of reservoirs: Transactions American Geophysical Union, v. 34, pp. 407-418.

Chen, Chang-Ning, 1974, Evaluation and control of soil erosion in urbanizing watersheds: Proceedings National Symposium on Urban Rainfall and Runoff and Sediment Control, University of Kentucky, Lexington, Ky., pp. 161-173.

Collier, C. R., Pickering, R. J., and Musser, J. J., 1970, Influences of strip mining on the hydrologic environments of parts of Beaver Creek basin, Kentucky, 1955-66: U.S. Geological Survey Professional Paper $427-\mathrm{C}, 80 \mathrm{p}$.

Curtis, Willie R., 1979, Surface mining and the hydrologic balance: Mining Congress Journal, pp. 35-40.

Dyer, R., 1977, The effects of mine acid on the Pond River watershed in Western Kentucky: Water Resources Bulletin 13, 1069-1076, West Kentucky University, Bowling Green, Ky.

Grim, Elmore C., and Hil1, Ronald D., 1974, Environmental protection in surface mining of coal : EPA-670/2-74-093, National Environmental Research Center, Cincinnati, Ohio, 276 p. 
Herricks, E. E., and Shanholtz, V. 0., 1976, Predicting the environmental impact of mine drainage on stream biology: Transactions American Society of Agricultural Engineers, v. 19, no. 2, $271 \mathrm{p}$.

Hydrologic Engineering Center, 1974, Urban storm water runoff (STORM): U.S. Corps of Engineers, Davis, Calif.

Jennings, M. E., Carey, W. P., and Blevins, D. W., 1980, Field studies for verification of surface mining hydrologic models: Proceedings Symposium on Surface Mining Hydrology, Sedimentology and Reclamation: University of Kentucky, Lexington, Ky., pp. 47-54.

Johanson, Robert C., Imhoff, John C., and Davis, Harley H., Jr., 1980, Users manual for hydrological simulation program-Fortran (HSPF): EPA-600/9-80-115, Environmental Research Laboratory, Athens, Ga., $678 \mathrm{p}$.

Kathuria, D. Vir., Nawrocki, Michael A., and Becker, Burton C., 1976, Effectiveness of surface mine sedimentation ponds: EPA-600/2-76-117, Industrial Environmental Research Laboratory, Cincinnati, Ohio, $100 \mathrm{p}$.

Knisel, Walter G., 1980, CREAMS: A field-scale model for chemicals, runoff and erosion from agricultural management systems: U.S. Department of Agriculture, Conservation Research Report No. 26, 640 p.

Leavesley, G. H., Lichty, R. W., Troutman, B. M., and Saindon, L. G., 1981 (draft), Precipitation-runoff modeling system: Users manual: U.S. Geological Survey, $245 \mathrm{p}$.

Lumb, Alan M., 1974, Travel time of Georgia streams: Report No. ERC-1273, Environmental Resources Center, Georgia Institute of Technology, Atlanta, Ga., 80 p.

Lumb, Alan M., Wallace, James R., and James, L. Douglas, 1974, Analysis of urban land treatment measures for flood peak reduction: Report No. ERC0574, Environmental Resources Center, Georgia Institute of Technology, Atlanta, Ga., 146 p.

Metcalf and Eddy, Inc., University of Florida, Water Resources Engineers, Inc., 1971, Stormwater management model : Vol. I : 1102400C07/71, U.S. Environmental Protection Agency, Washington, D.C., 352 p.

Minear, R. A., and Tschantz, 1976, The effects of coal surface mining on the water quality of mountain drainage basin streams: JFWPCA, v. 48, no. 11 , pp. 2549-2569.

Musser, J. J., 1963, Description of physical environment and of strip-mining operations in parts of Beaver Creek basin, Kentucky: U.S. Geological Survey Professional Paper 427A, $25 \mathrm{p}$.

Overton, Donald E., and Crosby, Ernest C., 1979, Effects of contour coal strip mining on stormwater runoff and quality: Department of Civil Engineering, University of Tennessee, Knoxville, Tenn., 139 p. 
Puente, Celso, 1981, unpublished Environmental Impact Statement: U.S. Geological Survey.

Randall, Alan, 1978, Estimating environmental damages from surface mining of coal in Appalachia: A case study: EPA-600/2-78-003, Industrial Environmental Research Laboratory, Cincinnati, Ohio, $130 \mathrm{p}$.

Roeh1, J. W., 1962, Sediment source areas-delivery ratios and influencing morphological factors: International Association of Scientific Hydrology Publication 59, Commission on Land Erosion, pp. 202-213.

Rogowski, A. S., Pionke, H. B., and Broyan, J. G., 1977, Modeling the impact of strip mining and reclamation processes on quality and quantity of water in mined areas: A review: Journal of Environmental Quality $6(3)$, pp. 237-244.

Rohlf, Richard, and Warner, Richara, 1980, Determination of the probable hydrologic consequences of mining and assessment of the probable cumulative impacts of mining: Prepared for Symposium on Surface Mining Hydrology, Sedimentology and Reclamation, University of Kentucky, Lexington, Ky., $21 \mathrm{p}$.

Scott, Arthur G., 1980, An interim report on the investigation of flooding in the Tug Fork basin of Kentucky, Virginia and West Virginia: U.S. Geological Survey, Open-File Report 80-1188, 114 p.

Shumate, Kenesaw S., Smith, E. E., Ricca, Vincent T., and Clark, Gordon M., 1976, Resources allocation to optimize mining pollution control: EPA-600/2-76-112, Industrial Environmental Research Laboratory, Cincinnati, Ohio, 476 p.

Stall, John B., and Yang, Chih Ted, 1970, Hydraulic geometry of 12 selected stream systems of the United States: Report No. 32, Water Resources Center, Urbana, I11.

Sternberg, Y. M., and Agnew, A. F., 1968, Hydrology of surface mining--A case study: Water Resources Research.

Tomkiewicz, S. T., and Dunson, W. A., 1976, Aquatic insect diversity and biomass in a stream marginally polluted by acid strip mine drainage: Water Research, v. 11, pp. 397-402.

University of Kentucky, 1979, Symposium on surface mining hydrology, sedi mentology, and reclamation: Lexington, Ky., $353 \mathrm{p}$.

University of Kentucky, 1980, Symposium on surface mining hydrology, sedimentology, and reclamation: Lexington, Ky., $480 \mathrm{p}$.

U.S. Army Corps of Engineers, 1978, Special flood hazard information report, Tug Fork of Big Sandy River, Kentucky and West Virginia: Huntington, W. Va. 
U.S. Army Corps of Engineers, 1981, Tug Fork Valley, flood damage reduction plan: Huntington, W. Va.

U.S. Congress, 1977, The surface mining control and reclamation act of 1977 : Public Law 95-87, 30 U.S.C. 1201, Laws of 95th Congress, First Session.

U.S. Geological Survey, (in press), Hydrology of Area 13, Eastern Coal Province, Kentucky, Virginia, and West Virginia: Open-File Report 82-505.

Wilson, J. L., and Hamilton, D. A., 1978, Influence of strip mines on regional groundwater flow: Journal of the Hydraulic Division. American Society of Civil Engineers, v. 104, no. HY9, pp. 1212-1223.

Yorke, Thomas H., 1978, Impact assessment of water resources development activities: A dual matrix approach: Report No. FWS/0BS-78/82, U.S. Fish and Wildlife Service, Harpers Ferry, W. Va., 27 p. 